\title{
Syrian Arab Republic: 2009 Article IV Consultation-Staff Report; and Public Information Notice.
}

Under Article IV of the IMF's Articles of Agreement, the IMF holds bilateral discussions with members, usually every year. In the context of the 2009 Article IV consultation with the Syrian Arab Republic, the following documents have been released and are included in this package:

- $\quad$ The staff report for the 2009 Article IV consultation, prepared by a staff team of the IMF, following discussions that ended on December 22, 2009, with the officials of the Syrian Arab Republic on economic developments and policies. Based on information available at the time of these discussions, the staff report was completed on February 12, 2010. The views expressed in the staff report are those of the staff team and do not necessarily reflect the views of the Executive Board of the IMF.

- $\quad$ A Public Information Notice (PIN) summarizing the views of the Executive Board.

The policy of publication of staff reports and other documents allows for the deletion of market-sensitive information.

\author{
Copies of this report are available to the public from \\ International Monetary Fund • Publication Services \\ $70019^{\text {th }}$ Street, N.W. • Washington, D.C. 20431 \\ Telephone: (202) 623-7430 • Telefax: (202) 623-7201 \\ E-mail: publications@imf.org Internet: http://www.imf.org
}

\section{International Monetary Fund Washington, D.C.}




\section{INTERNATIONAL MONETARY FUND}

SYRIAN ARAB REPUBLIC

\section{Staff Report for the 2009 Article IV Consultation}

Prepared by the Staff Representatives for the 2009 Consultation

with the Syrian Arab Republic

Approved by Alan MacArthur and David Marston

February 12, 2010

- Discussions for the 2009 Article IV consultation were held in Damascus during December 7-22, 2009. The mission comprised Mr. Sakr (Head), Mms. Farahbaksh and Arbatli, and Messrs Al-Ghelaiqah and Dridi (all MCD). Mr. Shalaan (OED) joined the policy discussions.

- The mission met with Deputy Prime Minister Dardari, Minister of Finance AlHussein, former Minister of Economy Lutfi, former Head of the State Planning Commission Raddawi, Central Bank Governor Mayaleh, and representatives of financial institutions and nongovernment organizations.

- The Executive Board concluded the 2008 Consultation on January 9, 2008. The staff report and PIN are available on:

http://www.imf.org/external/pubs/cat/longres.cfm?sk=22702.0 


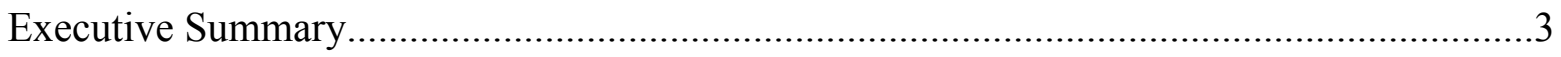

I. Background and Recent Economic Developments ...........................................................

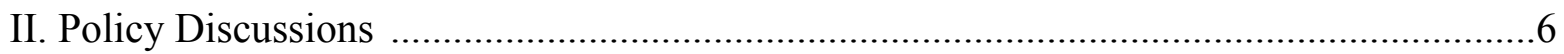

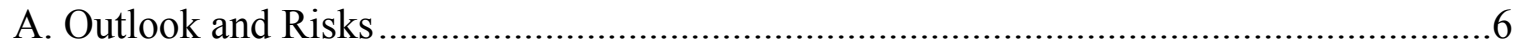

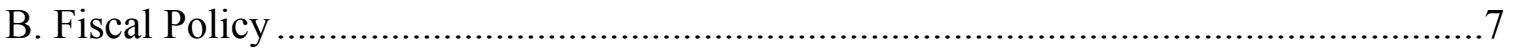

C. Monetary Policy and Financial Sector Reform ..........................................................

D. Structural Reforms and Other Issues ..................................................................13

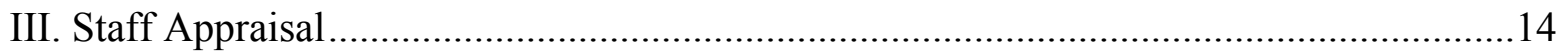

Text Boxes

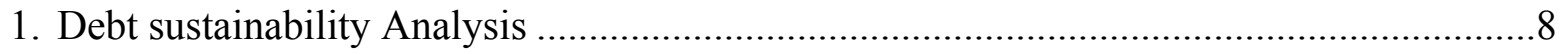

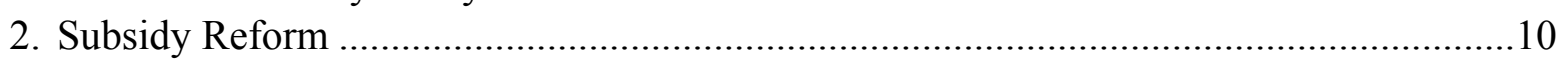

3. Financial Sector Developments .............................................................................12

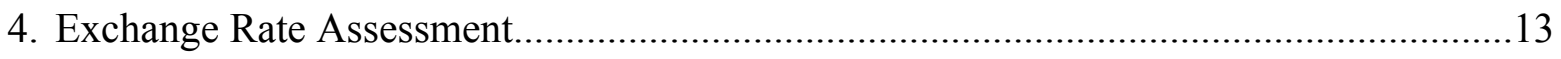

Figures

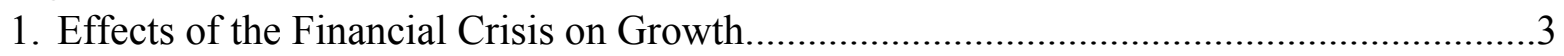

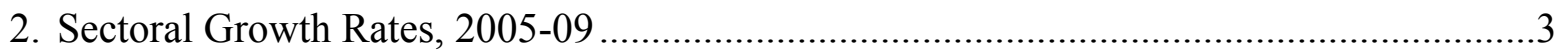

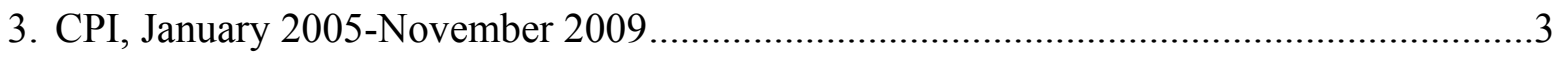

4. Foreign Trade, 2008

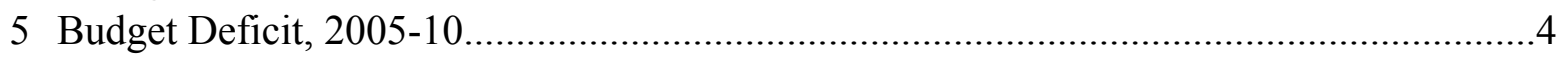

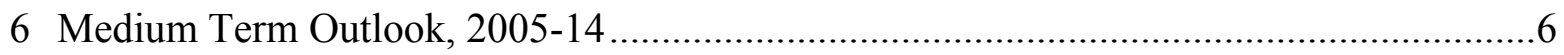

Tables

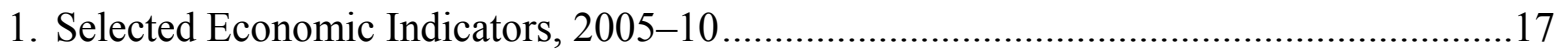

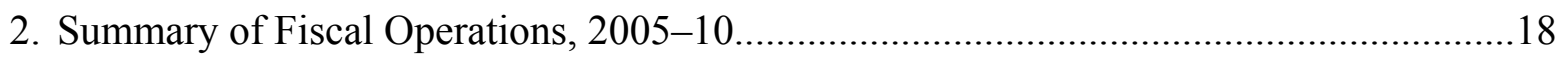

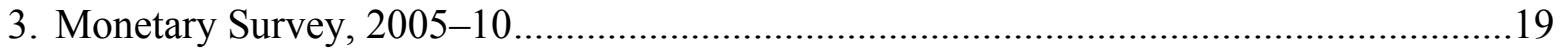

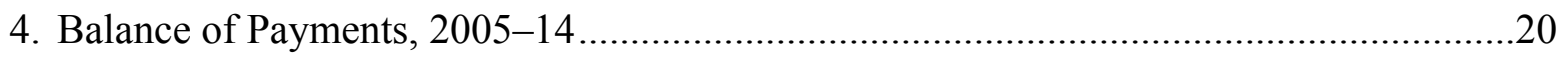

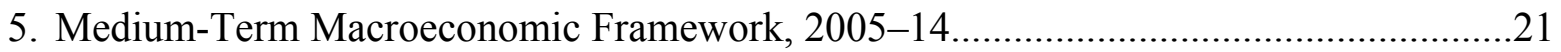

6. Financial Soundness Indicators of the Banking Sector, 2006-08...................................22

7. Public Sector Debt Sustainability Framework, 2004-14 ................................................23

7b.External Debt Sustainability Framework, 2004-14 ……………………….................24 


\section{Background}

\section{EXECUTIVE SUMMARY}

- The impact of the global financial crisis on Syria has been relatively moderate and mostly through linkages to trading partners in the region and Europe. Non-oil growth is estimated to have declined by 1.5 percentage points in 2009 to 4.5 percent. The fiscal and current account deficits are estimated to have widened somewhat, but remained at sustainable levels, and the level of official net foreign assets remained comfortable.

\section{Authorities' views}

- Measures taken in response to the global crisis and to support lending to investment projects are temporary and will be phased out over time.

- Quasi-fiscal operations that are conducted by public enterprises and state-owned banks will continue to be streamlined.

- Plans to modernize the monetary policy framework will be advanced, including by developing indirect monetary policy instruments such as treasury bills.

- Implementation of financial sector and other structural reforms will continue to promote the private sector, diversify the economy, and accelerate growth and employment creation.

\section{Staff recommendations}

- Gradually resume fiscal consolidation, including by revisiting the large increase in public investment budgeted for 2010, maintaining current expenditure restraint, and building on the progress made in reforming subsidies.

- Complete the remaining preparations for the introduction of the VAT in 2011 and improve public financial management.

- Continue with the implementation of the 2008 FSAP recommendations, and reform public banks. Reverse the increase in the regulatory ceiling on credit exposure, and phase out the differentiated reserves requirement.

- Allow exchange rate fluctuations within the de jure band around the SDR and gradually increase flexibility over the medium-term.

- Accelerate structural reforms, including by modernizing regulations, continuing to streamline the extensive subsidies system, and further liberalizing trade. 


\section{BACKGROUND AND RECENT ECONOMIC DEVELOPMENTS}

\section{The Syrian authorities have been implementing gradual, but wide-ranging}

reforms. These reforms are motivated by the challenges posed by the decline in oil production and the strategy initiated in the early 2000 s to transition toward a social market economy. The exchange rate has been effectively unified and restrictions on access to foreign exchange for current transactions appear to have been mostly eliminated. Private banks are now leading financial sector growth, and the Damascus stock exchange recently re-opened after being closed for 40 years. Taxes have been streamlined and the trade regime significantly liberalized. There was a limited cabinet reshuffle in January, but no change in economic policy is expected.

\section{The impact of the global financial crisis on Syria has been relatively moderate} and mostly through linkages to trading partners in the GCC and Europe. GDP growth is estimated to have decelerated in 2009 by 1 percentage point to 4 percent. Lower growth in manufacturing, construction, and services was partially offset by a moderate recovery in agriculture and a small increase in oil production.

Unemployment is estimated to have increased to almost 11 percent. Inflation declined sharply to about 2.5 percent, reflecting trends in global prices.
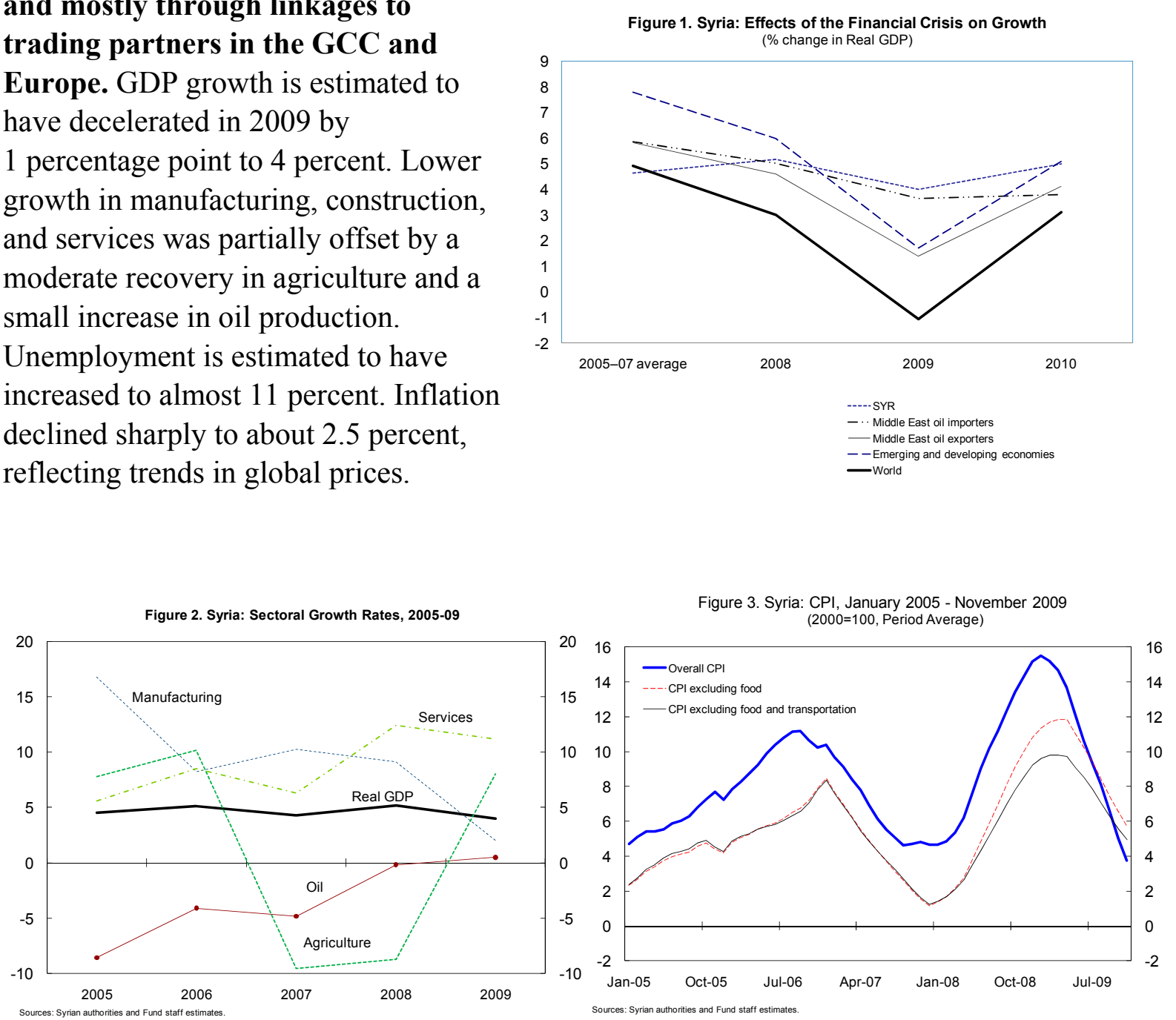
Figure 4. Syria: Foreign Trade, 2008
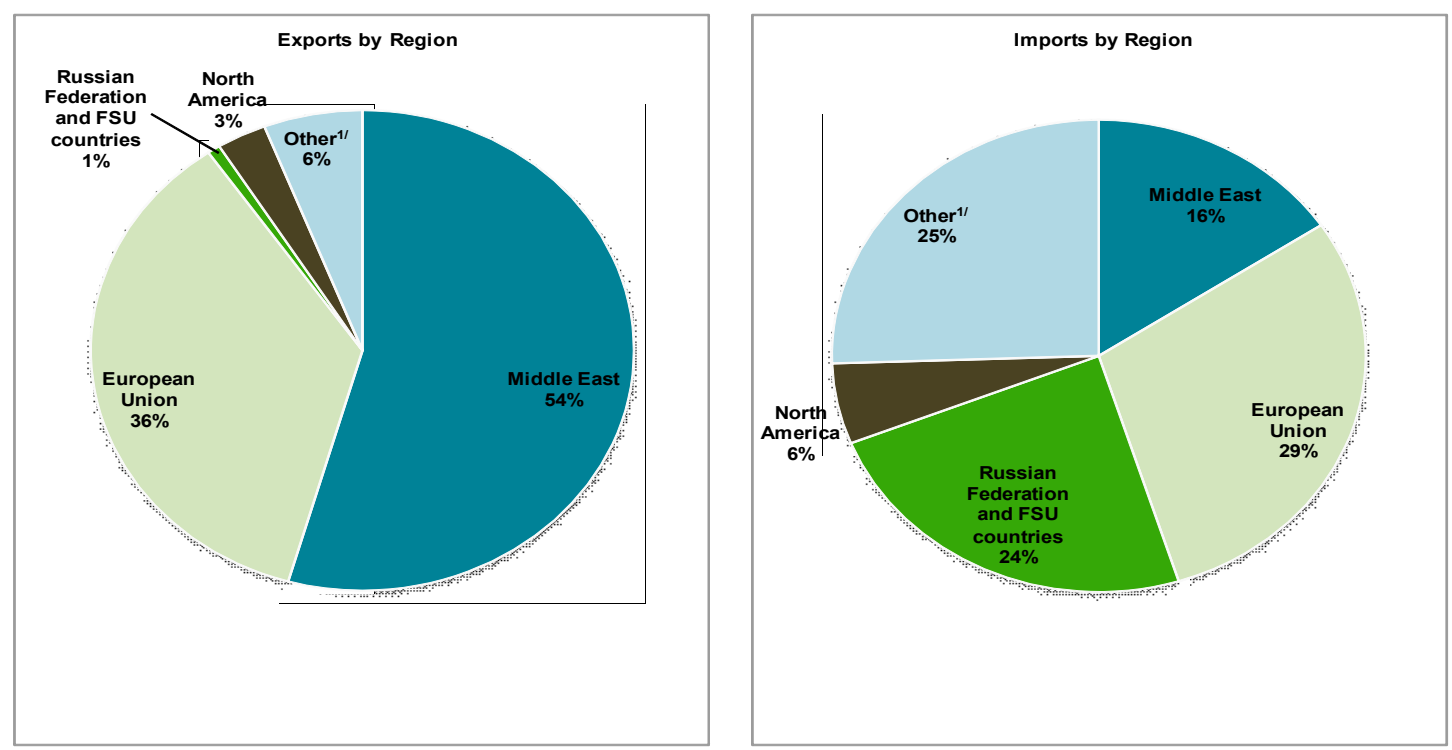

1/Includes China, India, Turkey, and other trading partners.

Source: Syrian Ministry of Economy and Trade.

3. Fiscal policy in $\mathbf{2 0 0 9}$ aimed at mitigating the impact of the global crisis.

Budgetary expenditure is estimated to have grown by about 5 percent of GDP, reflecting increases in public investments, as well as the wage bill part of which was to compensate for raising fuel prices. Non-oil revenue increased, partly due to strong tax collection, which resulted from improved administration and incentives to settle arrears. The recorded deficit is estimated to have widened in 2009 by about 2.5 percentage points to 5.5 percent of GDP.

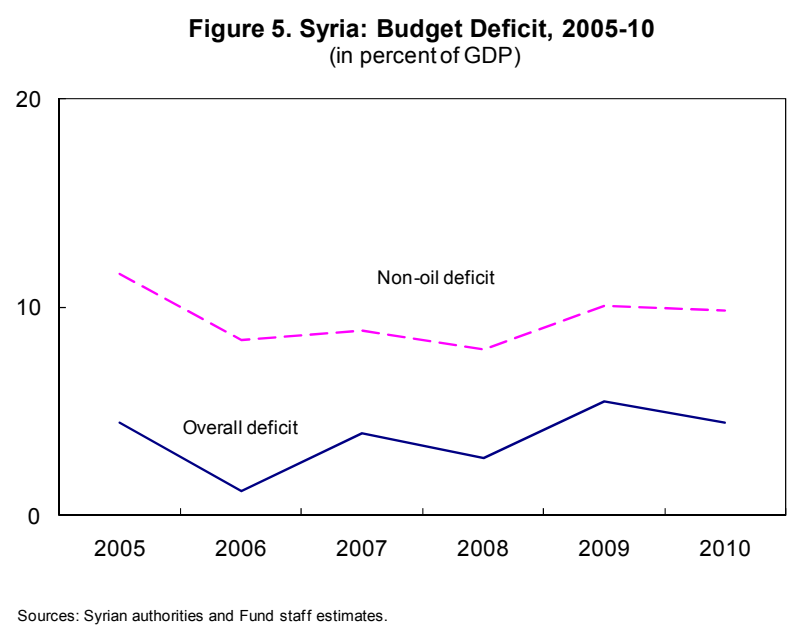

4. The external current account deficit widened to about 4.5 percent, as the decline in exports exceeded that of imports. However, tourism receipts were buoyant, and both FDI and remittances dropped only slightly. Gross reserves remained comfortable, at about US\$17 billion.

5. With the Syrian pound pegged to a basket (within a band), broad money is estimated to have grown by about 10 percent in 2009. Credit to public enterprises decelerated sharply due to the reduction in energy subsidies, which were financed by 
borrowing. Nonetheless, growth of credit to the private sector remained at about 25 percent, driven by the expansion of private banks.

6. The Central Bank of Syria (CBS) took some measures to ease the monetary stance and support lending to investment projects. These included: (i) reducing the reserve requirements by up to 5 percent for banks that increase lending to investment projects; (ii) requiring selected banks to cancel penalty on overdue debts and extend maturities; (iii) reducing the indicative deposit interest rates from 7-9 percent to 6-8 percent; and (iv) increasing the credit exposure limit for development projects from 25 percent to 35 percent for a single project. The CBS introduced additional conditions on the credit associated with the latter measure in order to safeguard its quality. The authorities also established a Lender of Last Resort facility, and increased the minimum capital requirement for banks from $\$ 30$ million to $\$ 200$ million for conventional banks, and from $\$ 100$ to $\$ 300$ million for Islamic banks (with 3 years grace period). Concomitantly, the ceiling on foreign ownership of banks' was increased from 49 percent to 60 percent.

7. The authorities also undertook a series of actions to mitigate the impact of the drought and higher diesel prices on agriculture. These included tax breaks for farmers, rescheduling of loans, cancelation of penalty on arrears, and increasing procurement prices of key crops. The government established the Agricultural Support Fund (ASF) in 2008 to replace some input subsidies with cash transfers to farmers. The ASF was allocated SP10 billion in the 2009 budget. In addition, the Ministry of Finance (MoF) introduced tax incentives to encourage companies to contribute to strategic objectives such as locating in remote areas, increase hiring, and placing initial public offers in the stock market.

8. Some progress has been made in advancing structural reforms, including simplifying investment procedures, modernizing accounting standards, and streamlining the tax system. Effective June 2009, the authorities raised the minimum thresholds for exemption from wage taxes. As an offsetting measure, the top income tax rate for individuals was increased to 22 percent (from 20 percent). However, the authorities recently introduced reference prices and customs duties that vary by country of origin to protect against unfair trade practices.

\section{Policy Discussions}

\section{A. Outlook and Risks}

\section{The outlook for $\mathbf{2 0 1 0}$ points to an overall strengthening in economic}

performance. The ongoing recovery in Syria's trading partners is expected to contribute to a gradual increase in exports, remittances, and FDI in 2010. Agriculture is likely to continue to recover from the severe drought of the past two years. Therefore, growth is projected at about 5 percent. The overall fiscal deficit is expected to narrow by about 1 percentage point 
of GDP, on account of current expenditure restraint and a rise in oil revenues. The external current account deficit is envisaged to narrow slightly, partly due to the moderation in the domestic public consumption.

10. The medium-term outlook is projected to continue to improve with the gradual global recovery and progress in domestic economic reforms. Growth is expected to strengthen to about 5.5 percent by 2014, despite the envisaged decline in oil output, with the ongoing rebound in agriculture and global recovery. The authorities' medium-term fiscal strategy aims to contain the overall deficit below 5 percent of GDP. The key pillars of this strategy are the introduction of a VAT in 2011, a further deepening of subsidies reform, and expenditure restraint. The fiscal deficit is, therefore, projected to narrow to 3.4 percent of GDP and to moderately increase to 3.8 percent of GDP by 2014 due to the steady decline in oil revenue. The external current account deficit will likely

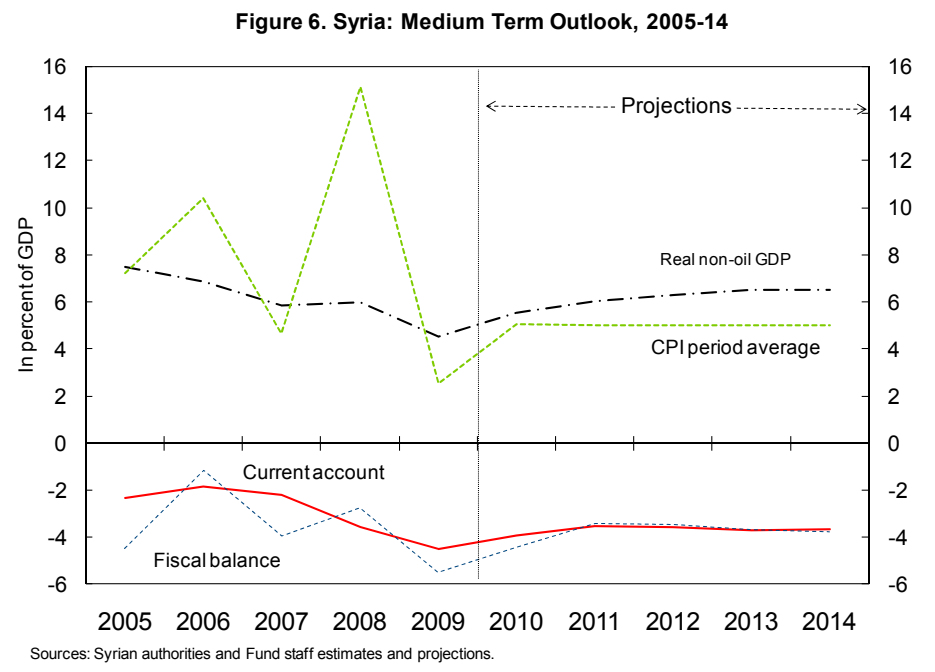
stabilize at 3.7 percent of GDP due to strengthening of non-oil exports and tourism receipts. A delay in global recovery or faltering reform implementation could worsen the outlook and impede Syria's economic growth.

\section{B. Fiscal Policy}

11. The consolidation of public finances over the past few years provided room for the authorities to take counter-cyclical measures to mitigate the effects of the global economic crisis. Assuming somewhat similar implementation ratios as in the past, the 2010 budget implies a moderate tightening of the fiscal stance underpinned by a slight improvement in revenue and current expenditure restraint. In nominal terms, the budget provides for a 12.5 percent expenditure growth over the 2009 preliminary outcome. It includes a small increase in current expenditure, mostly due to a moderate increase in wages. It also provides for a 30 percent increase in capital outlays compared to the 2009 preliminary outcome (and 19 percent compared to the 2009 revised budget). Cash transfers replacing the diesel coupons are envisaged to increase by about 0.5 percent of GDP. The authorities are confident that the projected economic recovery in 2010 will allow them to resume fiscal consolidation. They intend to continue to restrain current expenditures and rationalize capital outlays. In recent years, the fiscal deficit has been smaller than what was envisaged in the original state budget. The authorities also aim at continuing to allow the 
private sector to take the lead in implementing some investment programs, including in the context of public-private partnership (PPP) arrangements with adequate safeguards.

\section{The authorities are determined to continue to modernize the subsidies system to} further enhance fiscal gains, efficiency, and the targeting of assistance. They replaced the universal diesel coupons with targeted cash transfers to compensate vulnerable households. Furthermore, many agricultural subsidies are now being delivered in the form of targeted cash transfers through the ASF.

\section{Box I. Debt Sustainability Analysis}

Public debt remains low since the 2005 rescheduling of the debt to Russia, and fiscal reforms have advanced. However, the authorities need to continue their fiscal effort reform in the period ahead in view of the likely expenditure pressures associated with plans to improve infrastructure and increase access to basic services.

Based on the authorities' ongoing reforms, public debt should remain at manageable levels. Debt is expected to increase only moderately, to about 25 percent of GDP by 2014, despite the substantial decline in oil revenue. The outlook is also sustainable if the recent years' trend is used to derive assumptions. Holding the key debt-dynamics variables (e.g. the real GDP growth and the primary fiscal balance) constant at their 10-year historical averages produces an improvement in the debt-to-GDP ratio by about 10 percent by 2014 . Holding the primary deficit constant at about 5 percent of GDP, the preliminary outcome of 2009, would lead to an increase in the debt ratio to about 30 percent by 2014 .

Sensitivity analysis of the baseline scenario indicates that public debt would remain sustainable under various shocks. A one-half standard deviation in the primary balance from the baseline assumption would result in a debt ratio by 2014 about 4 percentage points higher than in the baseline. Applying a similar shock to GDP growth leads to a debt ratio about 6.5 percentage points higher by 2014 than in the baseline. The most significant outcome was generated by a 10 percent of GDP increase in other debt-creating shocks (e.g. larger contingent liabilities related to public enterprises), leading to a debt ratio in 2014 of about 7.5 percentage points of GDP higher than in the baseline.

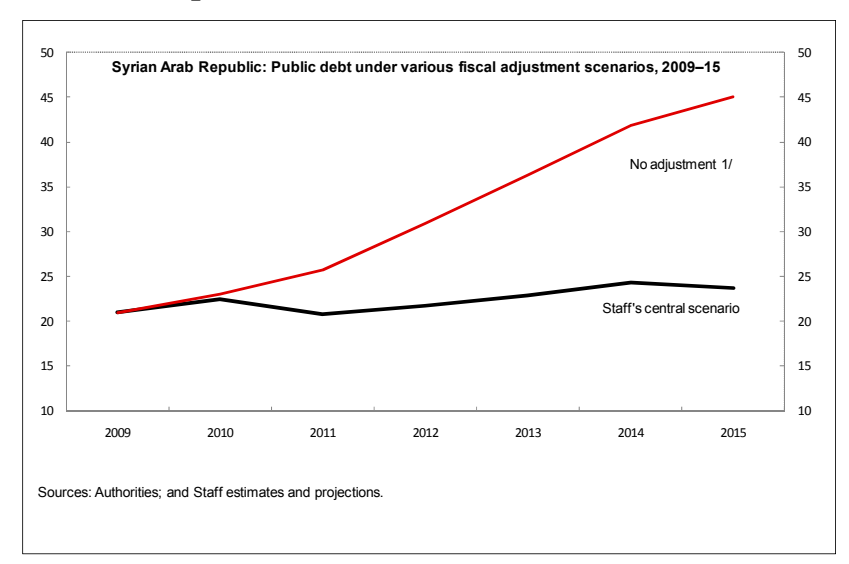

However, if the reforms underlying the baseline scenario falter, the fiscal outlook would significantly deteriorate. For example, a substantial delay in the implementation of the VAT, a re-emergence of large implicit fuel subsidies, and waning efforts to control wages and rationalize capital spending could lead to growing fiscal deficits and public debt ratios rising to about 50 percent of GDP. 
13. The MoF plans to introduce the VAT in 2011. Achievements in this area include the drafting of the VAT law and a tax procedures code, the establishment of the large taxpayer office and the General Commission for Taxes and Fees (GCTF), and substantial modernization of customs. The authorities stressed that the delay experienced in launching the VAT, which was originally planned for 2008 , was due to vital preparations of the tax administration and the public to ensure a successful introduction.

14. The authorities are cognizant of the need to further improve public expenditure monitoring and management. The current and capital budgets have been effectively integrated, and are now prepared and implemented by the MoF. For the first time, a program- and performance-based budgeting approach was adopted for the agriculture and education sectors in the 2010 budget. The authorities intend to further streamline the substantial quasi-fiscal operations that are conducted by public enterprises and state-owned banks. They plan to gradually bring on budget the remaining quasi-fiscal operations that are conducted by these entities, and improve the timeliness of expenditure reporting by the regional entities.

\section{Monetary Policy and Financial Sector Reform}

15. The scope for monetary policy independence will remain limited over the medium-term in view of the exchange rate arrangement. The authorities intend to continue their efforts to enhance the monetary policy framework. As part of their reform agenda, they are planning to gradually replace administrative tools for conducting monetary policy with market-based tools. If issuance of treasury bills is further delayed, the CBS would consider issuing its own certificates of deposits. The authorities indicated that the transfer of international reserves from the Commercial Bank of Syria (CBoS) to CBS has been completed, in line with the FSAP recommendation.

\section{In the authorities' view, some measures taken in response to the global crisis} and to support lending to investment projects are temporary and will be phased out over time. Staff noted that differentiated reserve requirements, based on the volume of lending for investment purposes, can encourage bank financing of less profitable projects. Also, it will be important to phase out the public banks' preferential lending schemes in order for banks to allocate their credit based on their own internal lending criteria.

Furthermore, the recent increase in the credit exposure limit for development projects could increase banks' vulnerabilities. 


\section{Box II. Subsidy Reform}

The authorities have taken important steps in reforming the energy subsidies. The prices of key petroleum products were increased in 2008, saving about 7 percent of GDP in implicit subsidies. To mitigate the impact of the higher prices, the authorities increased public wages and issued coupons, allowing every

\begin{tabular}{lcc}
\hline Energy Subsidy Reforms & 2008 & 2009 \\
\hline $\begin{array}{l}\text { Price Adjustments } \\
\text { Gas Oil (Diesel) }\end{array}$ & 7.3 to 25 SP/liter & 25 to 20 SP/liter \\
Fuel Oil & 6 to 9 SP/liter & $\ldots$ \\
Kerosene & 22.7 to 40 SP/liter & $\ldots$ \\
Gasoline & 36 to 40 SP/liter & $\ldots$ \\
\hline $\begin{array}{l}\text { Compensatory Measures } \\
\text { Public wage increase }\end{array}$ & $25 \%$ & $\ldots$ \\
Diesel coupons & 1000 liters per household at 9 & $\ldots$ \\
Cash Transfers & SP/liter & 10,000 SP for eligible households
\end{tabular}
household to buy up to 1000 liters of diesel at a lower price. These compensatory measures amounted to about 4.5 percent of GDP.

Notwithstanding the significant price increases, implicit subsidies remained at about 8.3 percent of GDP as international prices increased.

The universal diesel coupons were replaced by targeted cash transfers in 2009. The criteria applied in determining eligibility for transfers are based on income, asset ownership, and the utility bill. Approximately half of the Syrian households are likely to benefit from these transfers. Furthermore, unlike the cost of the coupons which was born by the state-owned oil distribution company, the cash transfers will be funded directly from the budget.

The increase in domestic energy prices reduced the cross-border leakage of subsidies, as reflected in the subsequent sharp reduction in diesel and fuel oil consumption. The implicit price subsidy declined sharply with the drop in international oil prices

\begin{tabular}{lcc}
\hline Energy Subsidies, as \% of GDP & 2008 & 2009 \\
\hline Total subsidy & 12.9 & 4.9 \\
Price subsidy (extrabudgetary) & 8.3 & -1.3 \\
Budgetary compensatory measures & 4.5 & 6.2 \\
\hline Sources: Oil Marketing Office, Ministry of Oil, Mahroukat and Fund staff estimates
\end{tabular}
in 2009. Nonetheless, the cumulative compensatory measure is estimated at about 6 percent of GDP, resulting in a still large, but more efficient subsidy to consumers. However, if domestic prices are not adjusted to reflect future changes in international prices, the current price gap will widen again, and so will leakage.

The government also took important steps to reform agricultural subsidies through the introduction of ASF to manage and streamline inputs subsidies. To mitigate the effects of the reduction in the implicit diesel subsidy and the liberalization of the fertilizer market in 2009, the ASF started to make targeted cash transfers to farmers.

\section{The CBS views further strengthening of bank supervision as a priority. In} particular, public banks now report on a regular basis their key financial sector indicators to the CBS. However, data for some of these banks may not reflect their true condition due to outdated accounting practices. The CBS has made progress in implementing the 2008 FSAP recommendations. Nonetheless, realization of a number of these recommendations requires amending the central bank law. Efforts are underway to prepare banks for the implementation of Basle II, including by requiring them to strengthen their internal risk assessment procedures. The authorities do not see a problem with the strong growth of private credit in view of the strengthening of the supervisory framework, low level of 
financial intermediation, and the fact that many of the new banks are subsidiaries of well established foreign banks with good risk assessment capabilities.

18. The impact of the global crisis on the financial sector has been limited due to the low degree of its global exposure and CBS's prudential requirements. The capital adequacy ratio for the consolidated banking sector is reported at about 20 percent. Banks continued to be liquid and moderately profitable. The average non-performing loans (NPL) ratio is low. However, the NPL of public banks (6 percent) is likely to be significantly understated as these banks do not classify many of their loans that are in arrears as bad loans since most of them are implicitly guaranteed by the government. In general, roll-over of bad loans is extensive, hindering a meaningful calculation of NPLs. The recent CBS regulation limiting roll-overs should help clarify the true position of these banks in the period ahead. Also, recent decisions to reschedule loans will be limited to sectors strongly impacted by the global crisis and the drought.

19. The Syrian pound appreciated by about 7 percent against the dollar in 2008 in nominal terms. This contributed, along with the high domestic inflation that year, to a real effective appreciation of about 14 percent. About half of that real appreciation was reversed during 2009 with the substantial depreciation of the dollar against the Euro and the decline in Syria's domestic inflation. Econometric estimates, which suffer from serious data shortcomings, suggest that the real exchange rate of the pound may be moderately overvalued relative to its medium-term equilibrium level (Box IV). The authorities have stressed that the exchange rate reflects market forces and that it is competitive as evidenced by the rapid growth of exports prior to the global recession of 2009. The staff does not recommend a change in the current nominal exchange rate level in the present context, and in view of the data shortcomings highlighted above. 


\section{Box III. Financial Sector Developments}

The Syrian authorities have embarked on an ambitious reform agenda to modernize the financial sector and improve intermediation. A number of laws and regulations have been put in place; private banks, insurance companies, and micro credit institutions have been established; and banking supervision has been strengthened. Furthermore, modernization of the CBS has continued, and substantial progress toward current account convertibility and exchange rate unification has been made. Moreover, the authorities fully liberalized bank lending rates and rates on foreign currency deposits and loans.

The share of private banks has grown considerably since they were first established in 2004. As of September 2009, there were 12 private banks (including 2 Islamic banks) with assets equivalent to about 24 percent of total banking sector assets. Their total deposits have grown by about 12-16 percent annually since 2006 . Overall, banking intermediation has increased substantially, although it still remains low by regional standards.

Despite the achievements made thus far, considerable challenges remain, including establishing indirect monetary instruments, reducing the role of the government in credit allocation, and removing the large excess liquidity in the banking system. The authorities are considering replacing administrative tools for conducting monetary policy, including controls on banks' domestic currency deposit rates with issuance of treasury bills. In this context, it is important that interest rates are fully liberalized to allow for full transmission of policy signals. Also, reserve requirements, which introduce distortions and complicate monetary management as the CBS moves forward with its plan to introduce indirect monetary instruments will need to be unified.
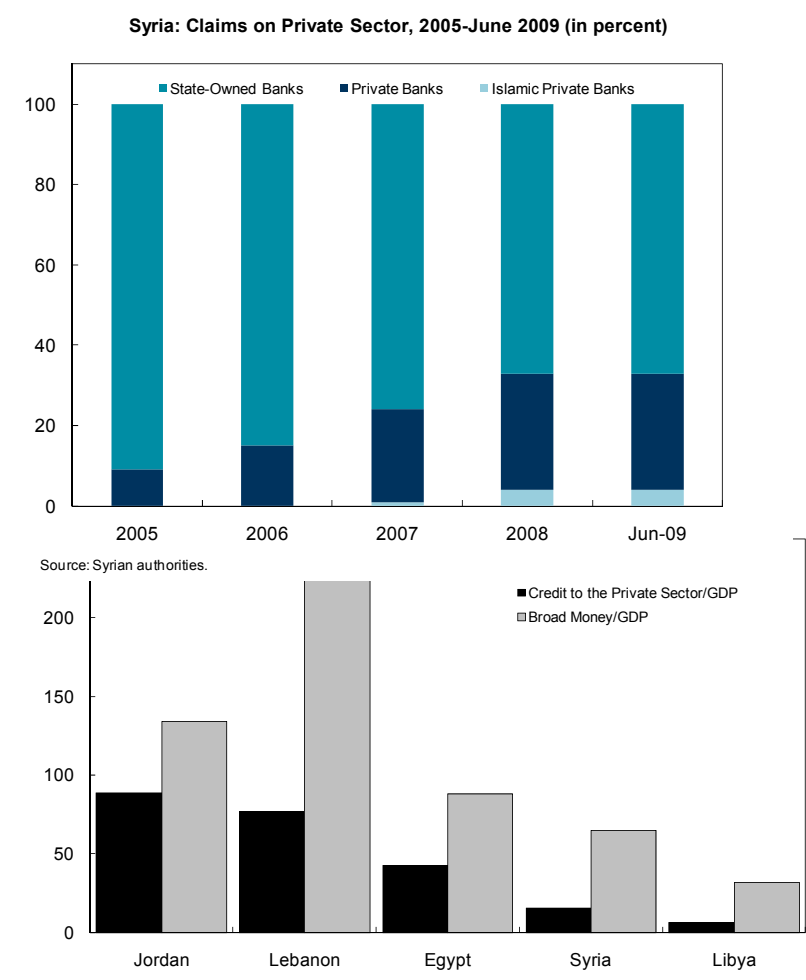
Sources: IFS; and Fund staff estimates

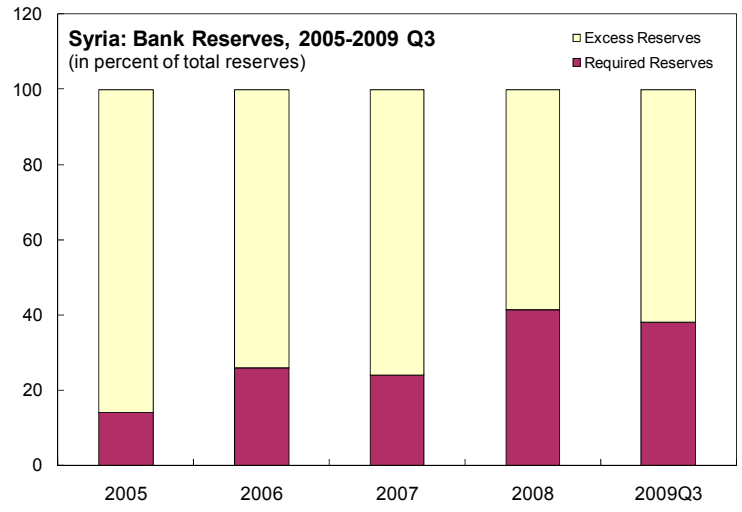

Source: Central Bank of Syria

Preferential lending schemes and directed credit to priority sectors should be phased out. Finally, considerations can also be given to securitizing government debt to CBS in order to remove excess liquidity. 


\section{Box IV. Exchange Rate Assessment}

Econometric estimates suggest that the pound may be moderately overvalued in real effective terms at end-2008. This has been partly corrected during 2009 with the depreciation of the dollar against the euro. However, the estimates, which utilized CGER methodologies 1/, are not reliable due to serious data shortcomings. Syrian balance of payments statistics and national accounts need significant improvement, and the data used by staff are in many cases only estimates.

The macroeconomic balance approach indicates an overvaluation of the pound by about 10-15 percent. Based on a panel regression, the equilibrium current account norm for Syria would be a surplus of about 1 percent of GDP. This compares with a projected deficit of about 3.7 percent of GDP. The set of determinant variables in this approach include the fiscal balance, population growth, NFA, oil balance, and per capita income.

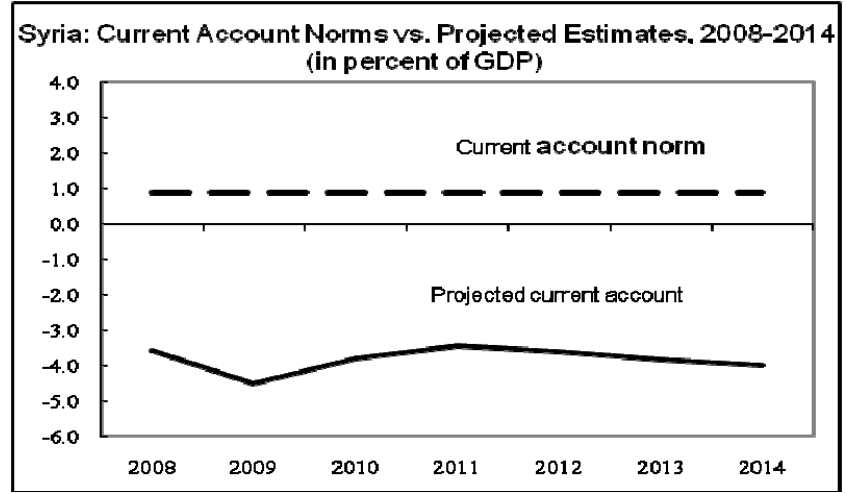

The equilibrium real exchange rate (ERER) methodology points to an overvaluation of the pound by about 1525 percent at end-2008. This methodology utilizes a vector error correction model to estimate the ERER using as the determining variables oil income, net foreign assets, openness to trade, government expenditure, and relative productivity.

The external sustainability approach also indicates an overvaluation of the pound. The results range from $10-15$ percent, depending on the assumptions used. The

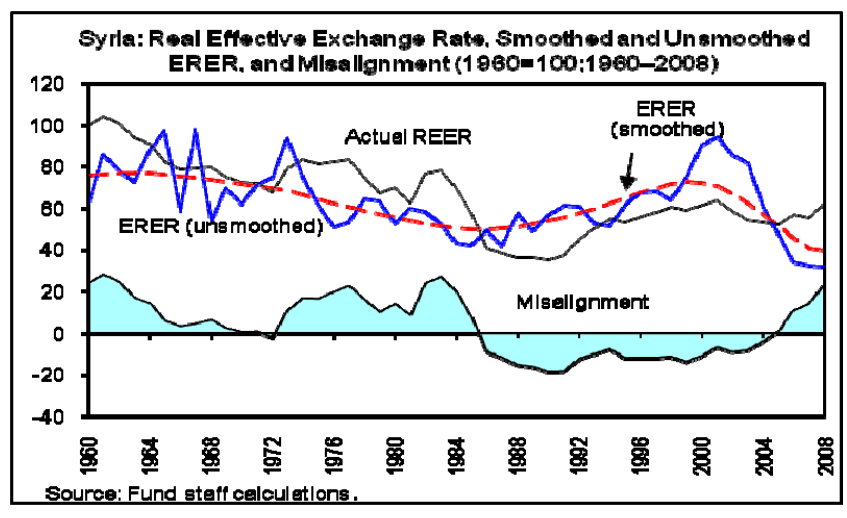
outcome depends on whether the objective is to keep constant the annuity from oil wealth in real terms, in real terms per capita, or as a percent of GDP.

1/ www.imf.org/external/np/pp/eng/2006/110806.pdf

\section{Structural Reforms and Other Issues}

\section{The authorities intend to continue to advance structural reforms in order to} accelerate growth, diversify the economy, and create employment. Progress has been made in many areas, including reducing import tariffs, shortening the import negative list, reforming fuel and agricultural subsidies, and establishing a one-stop window for approving private investment. Furthermore, to further liberalize current transactions, each citizen is now allowed to purchase up to $\$ 10,000$ per month from a local bank and to transfer them abroad in payment for current transactions or credit cards bills. The authorities noted that 
reference prices and customs duties that vary by country of origin were put in place in order to protect against unfair trade practices.

\section{Staff Appraisal}

21. The impact of the global financial crisis on Syria has been relatively moderate. Preliminary data for 2009 indicate that non-oil growth decelerated as lower growth in most sectors was only partially offset by a moderate recovery in agriculture. Inflation declined sharply, reflecting trends in the global prices of basic commodities. Despite the important progress made in subsidies reforms, the fiscal deficit widened as the consolidation of public finances in the past few years provided room for the authorities to implement countercyclical measures to mitigate the effects of the global economic crisis. The current account deficit increased slightly, as the decline in exports exceeded that of imports. Tourism receipts, however, remained buoyant, and both FDI and remittances dropped only slightly despite the global economic crisis.

22. The widening in the fiscal deficit in $\mathbf{2 0 0 9}$ was appropriate to mitigate the impact of the global recession. Furthermore, this widening in the fiscal deficit in 2009 partly reflects enhanced fiscal transparency as substantial extra-budgetary spending related to petroleum subsidies was brought on budget. A gradual resumption of fiscal consolidation going forward is necessary in order to preserve fiscal sustainability. In this connection, it would be important to revisit the large increase in public investment budgeted for 2010, especially after its large increase in 2009 . This would be more in line with absorptive capacity and would help reduce the overall fiscal deficit to about 4.5 percent of GDP. Furthermore, the staff urges the authorities to ensure that increases in public wages are linked to performance and to civil service reform.

\section{The commendable recent reforms of petroleum subsidies have led to} considerable efficiency gains and a reduction in waste and leakages as reflected in the decline in domestic consumption. The replacement in December 2009 of the diesel coupons with cash transfers is likely to enhance the targeting of assistance and consolidate efficiency and fiscal gains. The staff encourages the authorities to prevent a re-emergence of the large inefficient price subsidies of the past.

\section{The substantial progress in the preparation for the VAT is welcome, but} further efforts are needed. In particular, it would be important to make progress in reorganizing tax administration, including by shifting more responsibilities to the GCTF. The staff supports the streamlining of the tax system, and advises against a further increase in the personal income tax rates. The staff encourages the authorities to streamline excise taxes in line with the recommendations of past technical assistance missions. 
25. The efforts to improve public financial management are welcome and should continue. The budget classification should be further enhanced to reflect standardized economic classifications. In addition, it is important to support the plan to cast the budget formulation and execution in a medium-term framework by further empowering the newly established Fiscal Forecasting and Planning Units at the MoF and facilitating a more timely flow of data and information between these units and the different departments at the MoF. The staff encourages the authorities to expand the use of the program- and performancebased budgeting approach. It would also be important to bring on budget the remaining quasi-fiscal operations.

26. The staff recommends a shift in the financing of the budget deficit from bank borrowing to issuing treasury bills. The interest rate on these bills should be marketdetermined. At the same time, it would be important to ensure that public investment projects yield high economic and social return in order to justify the cost of their financing.

27. The staff welcomes the progress made in implementing the reform agenda to modernize the CBS and the monetary policy framework. Enhancing the CBS operational independence will be important to strengthen its ability to formulate and implement monetary policy. The staff also encourages the authorities to utilize treasury bills as an instrument of monetary policy to withdraw excess liquidity. Otherwise, the CBS would have to issue its own certificates of deposit. Considerations should also be given to securitizing the stock of government debt to the CBS.

28. Staff encourages the authorities to phase-out some of the decisions that were taken in response to the global crisis. The legitimate intended objectives of differentiated reserve requirements or increased credit exposure limits for development projects can be achieved through other means that are more effective and entail lower risks for banks and lesser burden for the supervision department.

\section{The staff welcomes the good start at implementing the recommendations of} the 2008 FSAP report, including by strengthening the regulatory and supervisory framework and improving collection of data on public banks. The authorities are encouraged to continue to strengthen supervision in order to maintain the health of the financial sector, especially in view of the rapid growth of private banks' credit. The staff also encourages the authorities to adopt the amended central bank law as soon as possible.

30. Priority in the period ahead should be placed on public banks' reform. The staff welcomes the closer collaboration between the MoF and the CBS regarding supervision of these banks. Strengthening the CBS's supervisory and regulatory independence with respect to these banks would ensure their compliance with prudential regulations and help address deficiencies identified in the supervisory process. 
31. The Syrian pound's de jure peg to a band around the SDR can provide a strong monetary anchor, while allowing some flexibility in the pound's rate vis-à-vis major currencies. In practice, the pound appears to be de facto pegged to a basket in which the dollar has a larger weight than its weight in the SDR basket. Adjusting the de facto basket in line with the de jure regime would be more consistent with Syria's direction of trade. The dollar has the largest share in the SDR basket, which is also consistent with the key role it has in foreign exchange markets and international trade pricing and payments. A gradual move toward greater flexibility over the medium-term as the monetary policy framework develops would further increase monetary policy independence and maintain external stability. Preliminary econometric estimates suggest that the pound may be moderately overvalued in real effective terms, although they are still subject to uncertainties given the serious data shortcomings. The staff, however, does not recommend a change in the current nominal exchange rate level in the present context.

32. The progress made in transition to a market economy is welcome, but the remaining structural reform agenda is substantial. Emphasis should be placed on further reducing the number of goods subject to administrative pricing, and modernizing of the legal and regulatory framework in order to encourage private investment and enhance competitiveness. The staff recommends that the authorities reverse the recent introduction of customs duties that vary by country of origin, and address suspected unfair trade practices by other measures such as enhancing customs' capacity to examine invoices through computerization and cross border cooperation.

33. The staff welcomes the authorities' intention to accept the obligations of Article VIII of the IMF's Articles of Agreement. The staff recommends that the authorities remove any remaining restrictions in preparation for the acceptance of the obligations of Article VIII. The staff stands ready to conduct a comprehensive review of the exchange system upon the authorities' request.

34. Staff urges the authorities to improve data quality and provision to facilitate better analysis of developments and guide policy formulation.

35. It is proposed that the next Article IV consultation take place on the standard 12-month cycle. 
Table 1. Syrian Arab Republic: Selected Economic Indicators, 2005-10

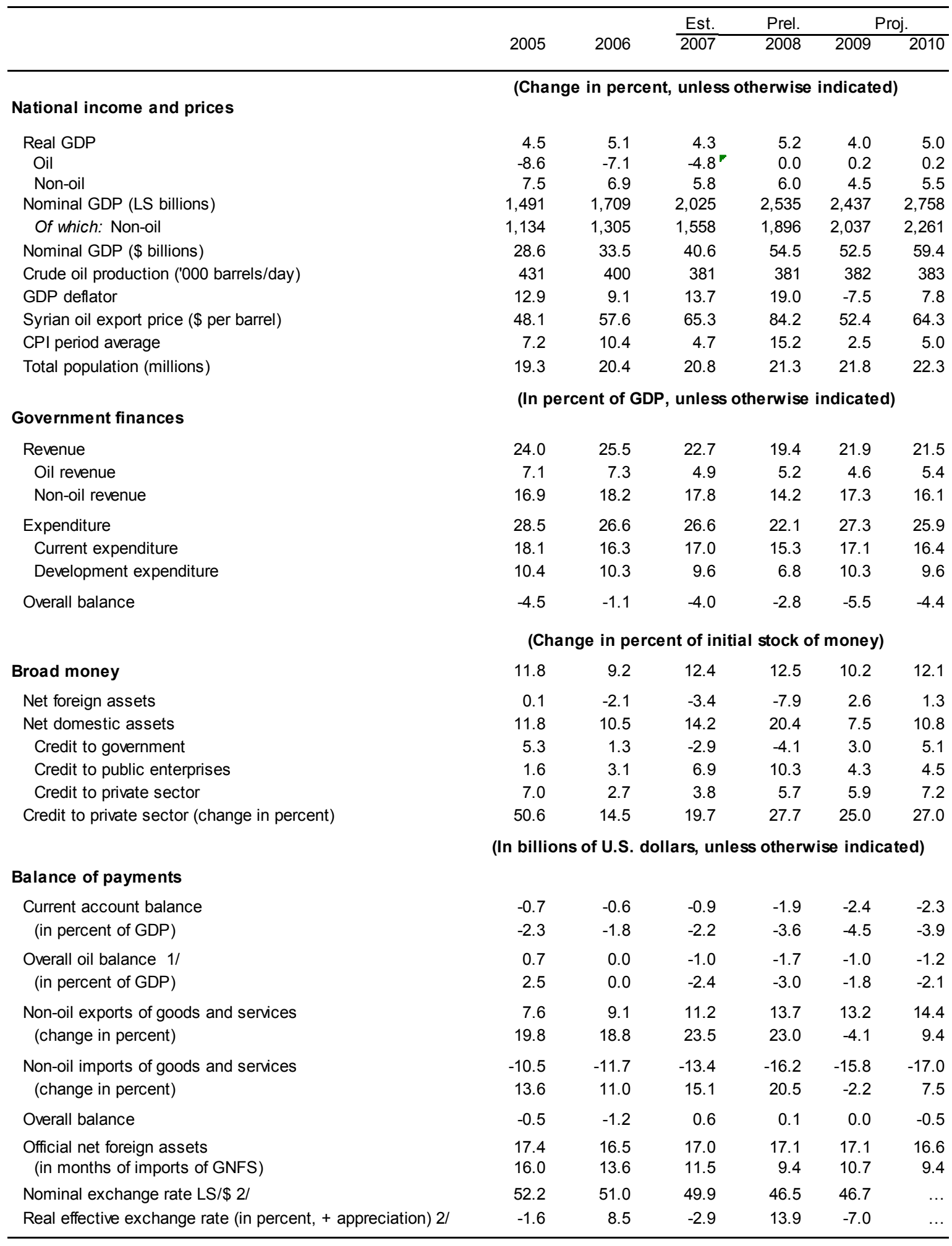

Sources: Syrian authorities; and Fund staff estimates and projections.

1/ Oil trade balance less profit of foreign oil companies.

2/ Trade-weighted average of official and parallel market rates before 2007. The REER for 2009 is for January-November. 
Table 2: Syrian Arab Republic: Summary of Fiscal Operations, 2005-10 1/ (In billions of Syrian pounds)

\begin{tabular}{|c|c|c|c|c|c|c|c|c|c|}
\hline & 2005 & 2006 & 2007 & $\frac{\text { Rev. Bud. }}{2008}$ & $\begin{array}{l}\text { Prel. } \\
2008\end{array}$ & Budget & $\begin{array}{l}\text { Proj. } \\
2009\end{array}$ & $\frac{\text { Budget }}{2010}$ & $\frac{\text { Proj. }}{2010}$ \\
\hline Revenue & 358.0 & 435.3 & 459.1 & 408.1 & 491.2 & 459.3 & 533.0 & 577.9 & 592.4 \\
\hline Oil & 106.2 & 124.7 & 99.6 & 90.3 & 131.4 & 85.7 & 111.2 & 148.8 & 148.8 \\
\hline Non-oil & 250.1 & 310.2 & 358.9 & 317.5 & 359.5 & 373.3 & 421.5 & 428.8 & 443.2 \\
\hline Tax & 160.3 & 198.6 & 221.4 & 214.1 & 258.0 & 243.4 & 296.2 & 299.4 & 319.2 \\
\hline Income and profit & 59.3 & 65.0 & 69.8 & 81.2 & 88.6 & 102.7 & 105.2 & 131.1 & 116.8 \\
\hline International trade & 30.7 & 32.9 & 33.4 & 25.9 & 33.1 & 28.1 & 37.7 & 31.4 & 40.7 \\
\hline Other indirect taxes & 70.3 & 100.7 & 118.2 & 107.1 & 136.3 & 112.6 & 153.2 & 136.9 & 161.6 \\
\hline Non-tax & 89.9 & 111.6 & 137.5 & 103.4 & 101.5 & 129.9 & 125.3 & 129.4 & 124.0 \\
\hline Of which: Public enterprise surpluses & 75.9 & 103.1 & 124.6 & 91.2 & 88.5 & 117.8 & 109.3 & 115.0 & 108.2 \\
\hline Other & $\begin{array}{r}15.8 \\
18\end{array}$ & 8.9 & 13.4 & 12.5 & 13.3 & 12.4 & 16.3 & 14.8 & 16.2 \\
\hline Of which: PSF revenue & 1.8 & 0.4 & 0.5 & 0.3 & 0.3 & 0.3 & 0.3 & 0.4 & 0.4 \\
\hline Expenditure & 424.5 & 454.9 & 539.3 & 602.1 & 561.3 & 681.4 & 666.4 & 749.9 & 714.6 \\
\hline Current expenditure & 270.1 & 278.4 & 344.5 & 420.7 & 388.3 & 406.4 & 415.8 & 422.9 & 451.0 \\
\hline Wages and salaries & 78.3 & 94.6 & 99.3 & 115.4 & 119.7 & 147.6 & 147.6 & 157.1 & 157.1 \\
\hline Goods and services & 21.5 & 22.5 & 24.3 & 30.6 & 27.5 & 30.5 & 26.5 & 33.2 & 29.9 \\
\hline Subsidies & 33.6 & 38.2 & 43.3 & 66.3 & 66.3 & 59.1 & 59.9 & 88.2 & 66.0 \\
\hline Of which: PSF expenditure & 29.6 & 33.5 & 39.4 & 33.5 & 33.5 & 35.3 & 35.3 & 38.4 & 38.4 \\
\hline Transfers & 40.5 & 35.8 & 37.7 & 58.9 & 44.6 & 68.9 & 81.4 & 36.9 & 96.7 \\
\hline Pensions \& social assistance & 16.3 & 19.0 & 21.3 & 23.8 & 23.8 & 32.0 & $32.0^{\top}$ & 0.0 & 34.1 \\
\hline Transfers to Public Enterprises & 24.3 & 16.8 & 16.5 & 35.2 & 20.9 & 36.9 & 36.9 & 36.9 & 37.6 \\
\hline $\begin{array}{l}\text { Cash fuel subsidies } \\
\text { Others }\end{array}$ & $\cdots$ & $\cdots$ & $\cdots$ & $\cdots$ & $\cdots$ & $\cdots$ & 12.5 & $\cdots$ & 25.0 \\
\hline Defense & 78.7 & 69.4 & 123.9 & 133.0 & 115.1 & 84.0 & 86.3 & 89.5 & 89.9 \\
\hline Interest payments & 17.4 & 17.9 & 16.0 & 16.5 & 15.1 & 16.2 & 14.1 & 18.0 & 11.4 \\
\hline Development expenditure & 154.4 & 176.5 & 194.8 & 181.4 & 173.1 & 275.0 & 250.6 & 327.0 & 263.6 \\
\hline Overall balance & -66.4 & -19.6 & -80.3 & -194.0 & -70.1 & -222.1 & -133.3 & -172.0 & -122.2 \\
\hline $\begin{array}{l}\text { Identified Financing } \\
\text { External }\end{array}$ & $\begin{array}{r}68.2 \\
3.2\end{array}$ & $\begin{array}{r}49.8 \\
-12.6\end{array}$ & $\begin{array}{r}35.3 \\
-10.3\end{array}$ & $\begin{array}{r}194.0 \\
29.1\end{array}$ & $\begin{array}{l}78.0 \\
-6.6\end{array}$ & $\begin{array}{c}222.1^{\top} \\
12.3\end{array}$ & $\begin{array}{r}190.6 \\
12.3\end{array}$ & $\begin{array}{r}172.0 \\
17.5\end{array}$ & $\begin{array}{r}122.2 \\
18.3\end{array}$ \\
\hline Domestic financing & 57.0 & 70.4 & 45.6 & 155.2 & 84.6 & 198.7 & 178.3 & 145.9 & 97.8 \\
\hline \multirow[t]{2}{*}{ Unidentified Financing } & -1.8 & -30.3 & 45.0 & $\cdots$ & -7.9 & $\cdots$ & -57.3 & $\cdots$ & 0.0 \\
\hline & \multicolumn{9}{|c|}{ (In percent of GDP) } \\
\hline Revenue & 24.0 & 25.5 & 22.7 & 16.1 & 19.4 & 18.8 & 21.9 & 21.0 & 21.5 \\
\hline Oil & 7.1 & 7.3 & 4.9 & 3.6 & 5.2 & 3.5 & 4.6 & 5.4 & 5.4 \\
\hline Non-oil & 16.8 & 18.2 & 17.7 & 12.5 & 14.2 & 15.3 & 17.3 & 15.5 & 16.1 \\
\hline Tax & 10.7 & 11.6 & 10.9 & 8.4 & 10.2 & 10.0 & 12.2 & 10.9 & 11.6 \\
\hline Non-tax & 6.0 & 6.5 & 6.8 & 4.1 & 4.0 & 5.3 & 5.1 & 4.7 & 4.5 \\
\hline Expenditure & 28.5 & 26.6 & 26.6 & 23.8 & 22.1 & 28.0 & 27.3 & 27.2 & 25.9 \\
\hline Current expenditure & 18.1 & 16.3 & 17.0 & 16.6 & 15.3 & 16.7 & 17.1 & 15.3 & 16.4 \\
\hline Wages and salaries & 5.3 & 5.5 & 4.9 & 4.6 & 4.7 & 6.1 & 6.1 & 5.7 & 5.7 \\
\hline Goods and services & 1.4 & 1.3 & 1.2 & 1.2 & 1.1 & 1.3 & 1.1 & 1.2 & 1.1 \\
\hline Subsidies & 2.3 & 2.2 & 2.1 & 2.6 & 2.6 & 2.4 & 2.5 & 3.2 & 2.4 \\
\hline Transfers & 2.7 & 2.1 & 1.9 & 2.3 & 1.8 & 2.8 & 3.3 & 1.3 & 3.5 \\
\hline Defense & 5.3 & 4.1 & 6.1 & 5.2 & 4.5 & 3.4 & 3.5 & 3.2 & 3.3 \\
\hline Interest payments & 1.2 & 1.0 & 0.8 & 0.7 & 0.6 & 0.7 & 0.6 & 0.7 & 0.4 \\
\hline Development expenditure & 10.4 & 10.3 & 9.6 & 7.2 & 6.8 & 11.3 & 10.3 & 11.9 & 9.6 \\
\hline Overall balance & -4.5 & -1.1 & -4.0 & -7.7 & -2.8 & -9.1 & -5.5 & -6.2 & -4.4 \\
\hline
\end{tabular}

Sources: Ministry of Finance; and staff estimates and projections.

1/ Central government budget and Price Stabilization Fund (PSF). 
Table 3. Syrian Arab Republic: Monetary Survey, 2005-10

\begin{tabular}{|c|c|c|c|c|c|c|}
\hline & 2005 & 2006 & $\frac{\text { Est. }}{2007}$ & $\begin{array}{l}\text { Prel. } \\
2008\end{array}$ & $\begin{array}{l}\text { Proj. } \\
2009\end{array}$ & $\begin{array}{l}\text { Proj. } \\
2010\end{array}$ \\
\hline & \multicolumn{6}{|c|}{ (In billions of Syrian pounds, end of period) } \\
\hline Foreign assets (net) & 748 & 733 & 708 & 591 & 635 & 658 \\
\hline Central bank & 135 & 148 & 190 & 214 & 215 & 198 \\
\hline Commercial banks & 613 & 584 & 518 & 377 & 420 & 460 \\
\hline Domestic assets & 452 & 578 & 765 & 1,065 & 1,189 & 1,386 \\
\hline Domestic credit & 550 & 635 & 740 & 917 & 1,136 & 1,443 \\
\hline Claims on public sector & 327 & 381 & 434 & 525 & 647 & 823 \\
\hline Central government (net) & 128 & 144 & 106 & 45 & 95 & 188 \\
\hline Public enterprises & 199 & 237 & 328 & 480 & 552 & 635 \\
\hline Claims on private sector & 223 & 255 & 305 & 389 & 487 & 618 \\
\hline Other items (net) & -97 & -57 & 25 & 149 & 54 & -56 \\
\hline Broad money & 1,201 & 1,311 & 1,473 & 1,656 & 1,824 & 2,044 \\
\hline Money & 698 & 687 & 732 & 827 & 919 & 1,031 \\
\hline Currency outside banks & 385 & 399 & 422 & 469 & 506 & 557 \\
\hline Demand deposits & 313 & 288 & 309 & 358 & 412 & 474 \\
\hline \multirow[t]{2}{*}{ Quasi-money } & 503 & 623 & 741 & 829 & 906 & 1,013 \\
\hline & \multicolumn{6}{|c|}{ (12-month change, in percent) } \\
\hline Broad money & 11.8 & 9.2 & 12.4 & 12.5 & 10.2 & 12.1 \\
\hline Money & 14.2 & -1.5 & 6.4 & 13.1 & 11.0 & 12.2 \\
\hline Quasi-money & 8.7 & 23.9 & 18.9 & 11.9 & 9.3 & 11.9 \\
\hline Net claims on government & 81.3 & 12.3 & -26.1 & -57.5 & 110.6 & 97.1 \\
\hline Claims on public enterprises & 9.2 & 18.9 & 38.5 & 46.5 & 15.0 & 15.0 \\
\hline \multirow[t]{2}{*}{ Claims on private sector } & 50.6 & 14.5 & 19.7 & 27.7 & 25.0 & 27.0 \\
\hline & \multicolumn{6}{|c|}{ (Change in percent of the initial stock of broad money) } \\
\hline Net foreign assets $1 /$ & 0.1 & -2.1 & -3.4 & -7.9 & 2.6 & 1.3 \\
\hline Domestic assets & 11.8 & 10.5 & 14.2 & 20.4 & 7.5 & 10.8 \\
\hline Central government (net) & 5.3 & 1.3 & -2.9 & -4.1 & 3.0 & 5.1 \\
\hline Public enterprises (net) & 1.6 & 3.1 & 6.9 & 10.3 & 4.3 & 4.5 \\
\hline Private sector & 7.0 & 2.7 & 3.8 & 5.7 & 5.9 & 7.2 \\
\hline Other items (net) & -2.1 & 3.3 & 6.3 & 8.4 & -5.7 & -6.0 \\
\hline
\end{tabular}

Sources: Central Bank of Syria; and Fund staff estimates and projections.

1/ For 2008 includes valuation effects. 
Table 4. Syrian Arab Republic: Balance of Payments, 2005-14 (In millions of U.S. dollars; unless otherwise indicated)

\begin{tabular}{|c|c|c|c|c|c|c|c|c|c|c|}
\hline & \multirow[b]{2}{*}{2005} & \multirow[b]{2}{*}{2006} & \multirow[b]{2}{*}{2007} & \multirow{2}{*}{$\frac{\text { Prel. }}{2008}$} & \multicolumn{6}{|c|}{ Proj. } \\
\hline & & & & & 2009 & 2010 & 2011 & 2012 & 2013 & 2014 \\
\hline $\begin{array}{l}\text { Current account balance } \\
\text { (In percent of GDP) }\end{array}$ & $\begin{array}{l}-661 \\
-2.3\end{array}$ & $\begin{array}{l}-614 \\
-1.8\end{array}$ & $\begin{array}{l}-885 \\
-2.2\end{array}$ & $\begin{array}{r}-1,940 \\
-3.6\end{array}$ & $\begin{array}{c}-2,365 \\
-4.5\end{array}$ & $\begin{array}{r}-2,319 \\
-3.9\end{array}$ & $\begin{array}{r}-2,327 \\
-3.5\end{array}$ & $\begin{array}{r}-2,580 \\
-3.6\end{array}$ & $\begin{array}{r}-2,944 \\
-3.7\end{array}$ & $\begin{array}{r}-3,211 \\
-3.7\end{array}$ \\
\hline $\begin{array}{l}\text { Goods } \\
\text { Exports, f.o.b. } \\
\text { Oil } \\
\text { Nonoil } \\
\text { Imports, f.o.b. } \\
\text { Oil } \\
\text { Nonoil }\end{array}$ & $\begin{array}{r}-1,270 \\
9,035 \\
4,286 \\
4,749 \\
-10,305 \\
-2,473 \\
-7,832\end{array}$ & $\begin{array}{r}-1,693 \\
10,224 \\
4,062 \\
6,162 \\
-11,917 \\
-2,884 \\
-9,033\end{array}$ & $\begin{array}{r}-2,825 \\
11,713 \\
4,355 \\
7,358 \\
-14,538 \\
-4,250 \\
-10,288\end{array}$ & $\begin{array}{r}-2,541 \\
15,238 \\
5,530 \\
9,708 \\
-17,779 \\
-5,654 \\
-12,125\end{array}$ & $\begin{array}{r}-2,529 \\
12,701 \\
3,493 \\
9,208 \\
-15,230 \\
-3,250 \\
-11,980\end{array}$ & $\begin{array}{r}-2,870 \\
14,183 \\
4,022 \\
10,162 \\
-17,053 \\
-4,102 \\
-12,951\end{array}$ & $\begin{array}{r}-2,923 \\
15,766 \\
3,977 \\
11,789 \\
-18,689 \\
-4,581 \\
-14,108\end{array}$ & $\begin{array}{r}-3,262 \\
17,632 \\
3,949 \\
13,684 \\
-20,895 \\
-5,479 \\
-15,416\end{array}$ & $\begin{array}{r}-3,746 \\
19,729 \\
3,835 \\
15,895 \\
-23,476 \\
-6,569 \\
-16,907\end{array}$ & $\begin{array}{r}-4,276 \\
22,167 \\
3,701 \\
18,466 \\
-26,443 \\
-7,838 \\
-18,605\end{array}$ \\
\hline $\begin{array}{l}\text { Services } \\
\text { Receipts } \\
\text { Travel and tourism } \\
\text { Freight and insurance } \\
\text { Government services } \\
\text { Other services } \\
\text { Payments }\end{array}$ & $\begin{array}{r}184 \\
2,874 \\
1,944 \\
181 \\
350 \\
398 \\
-2,690\end{array}$ & $\begin{array}{r}241 \\
2,891 \\
2,025 \\
184 \\
275 \\
407 \\
-2,650\end{array}$ & $\begin{array}{r}664 \\
3,823 \\
2,883 \\
188 \\
300 \\
452 \\
-3,159\end{array}$ & $\begin{array}{r}-40 \\
4,040 \\
3,150 \\
192 \\
270 \\
428 \\
-4,080\end{array}$ & $\begin{array}{r}110 \\
3,977 \\
3,213 \\
167 \\
231 \\
366 \\
-3,867\end{array}$ & $\begin{array}{r}186 \\
4,268 \\
3,470 \\
184 \\
238 \\
377 \\
-4,082\end{array}$ & $\begin{array}{r}267 \\
4,595 \\
3,748 \\
213 \\
245 \\
389 \\
-4,328\end{array}$ & $\begin{array}{r}434 \\
4,946 \\
4,047 \\
248 \\
252 \\
399 \\
-4,512\end{array}$ & $\begin{array}{r}494 \\
5,327 \\
4,371 \\
288 \\
258 \\
410 \\
-4,833\end{array}$ & $\begin{array}{r}616 \\
5,742 \\
4,721 \\
334 \\
266 \\
421 \\
-5,126\end{array}$ \\
\hline $\begin{array}{l}\text { Income } \\
\text { Credit } \\
\text { Debit } \\
\text { Oil companies' profits }\end{array}$ & $\begin{array}{r}-863 \\
395 \\
-1,258 \\
-1,088\end{array}$ & $\begin{array}{r}-935 \\
428 \\
-1,363 \\
-1,165\end{array}$ & $\begin{array}{r}-689 \\
594 \\
-1,283 \\
-1,085\end{array}$ & $\begin{array}{r}-1,149 \\
540 \\
-1,689 \\
-1,527\end{array}$ & $\begin{array}{r}-1,267 \\
290 \\
-1,557 \\
-1,213\end{array}$ & $\begin{array}{r}-1,084 \\
334 \\
-1,419 \\
-1,153\end{array}$ & $\begin{array}{r}-1,172 \\
347 \\
-1,519 \\
-1,246\end{array}$ & $\begin{array}{r}-1,212 \\
361 \\
-1,573 \\
-1,292\end{array}$ & $\begin{array}{r}-1,204 \\
375 \\
-1,579 \\
-1,289\end{array}$ & $\begin{array}{r}-1,130 \\
390 \\
-1,520 \\
-1,217\end{array}$ \\
\hline $\begin{array}{l}\text { Transfers } \\
\text { Credit } \\
\text { Workers' remittances } \\
\text { Debit }\end{array}$ & $\begin{array}{r}1,288 \\
1,302 \\
763 \\
-14\end{array}$ & $\begin{array}{r}1,772 \\
1,847 \\
770 \\
-75\end{array}$ & $\begin{array}{r}1,965 \\
2,040 \\
1,000 \\
-75\end{array}$ & $\begin{array}{r}1,790 \\
1,975 \\
1,250 \\
-185\end{array}$ & $\begin{array}{r}1,322 \\
1,605 \\
1,200 \\
-283\end{array}$ & $\begin{array}{r}1,449 \\
1,641 \\
1,236 \\
-192\end{array}$ & $\begin{array}{r}1,501 \\
1,703 \\
1,298 \\
-202\end{array}$ & $\begin{array}{r}1,461 \\
1,673 \\
1,428 \\
-212\end{array}$ & $\begin{array}{r}1,513 \\
1,735 \\
1,570 \\
-223\end{array}$ & $\begin{array}{r}1,579 \\
1,812 \\
1,727 \\
-234\end{array}$ \\
\hline $\begin{array}{l}\text { Capital and financial account balance } \\
\text { Capital account } \\
\text { Direct investment }\end{array}$ & $\begin{array}{r}669 \\
18 \\
776\end{array}$ & $\begin{array}{r}-586 \\
18 \\
875\end{array}$ & $\begin{array}{r}1,019 \\
118 \\
1,143\end{array}$ & $\begin{array}{r}868 \\
73 \\
1,627\end{array}$ & $\begin{array}{r}1,318 \\
73 \\
1,514\end{array}$ & $\begin{array}{r}1,771 \\
73 \\
1,850\end{array}$ & $\begin{array}{r}1,903 \\
73 \\
2,023\end{array}$ & $\begin{array}{r}2,594 \\
73 \\
2,659\end{array}$ & $\begin{array}{r}3,252 \\
73 \\
3,258\end{array}$ & $\begin{array}{r}3,856 \\
73 \\
3,521\end{array}$ \\
\hline Long-term government debt & 64 & -252 & -206 & -171 & -262 & -152 & -190 & -135 & -77 & -33 \\
\hline Short-term loans (net) & 100 & 132 & 152 & 180 & 179 & 199 & 217 & 240 & 266 & 295 \\
\hline Other & -189 & $-1,227$ & -36 & -661 & -7 & 0 & -3 & -3 & -1 & -1 \\
\hline Errors and & -467 & 3 & 461 & 1,128 & 1,033 & 0 & 0 & 0 & 0 & 0 \\
\hline $\begin{array}{l}\text { Overall balance } \\
\text { (in percent of GDP) }\end{array}$ & $\begin{array}{l}-459 \\
-1.6\end{array}$ & $\begin{array}{r}-1,198 \\
-3.6\end{array}$ & $\begin{array}{c}595 \\
1.5\end{array}$ & $\begin{array}{l}56 \\
0.1\end{array}$ & $\begin{array}{l}-14 \\
0.0\end{array}$ & $\begin{array}{l}-548 \\
-0.9\end{array}$ & $\begin{array}{l}-424 \\
-0.6\end{array}$ & $\begin{array}{r}14 \\
0.0\end{array}$ & $\begin{array}{l}308 \\
0.4\end{array}$ & $\begin{array}{l}645 \\
0.7\end{array}$ \\
\hline Financing & 459 & 1,198 & -595 & -56 & -23 & 548 & 424 & -14 & -308 & -645 \\
\hline & & & & & & & & & & \\
\hline $\begin{array}{l}\text { Gross official reserves } 1 / \\
\quad \text { (In months of imports of GNFS) }\end{array}$ & $\begin{array}{r}17,361 \\
16.0\end{array}$ & $\begin{array}{r}16,478 \\
13.6\end{array}$ & $\begin{array}{r}17,021 \\
11.5\end{array}$ & $\begin{array}{r}17,077 \\
9.4\end{array}$ & $\begin{array}{r}17,100 \\
10.7\end{array}$ & $\begin{array}{r}16,552 \\
9.4\end{array}$ & $\begin{array}{r}16,128 \\
8.4\end{array}$ & $\begin{array}{r}16,142 \\
7.6\end{array}$ & $\begin{array}{r}16,450 \\
7.0\end{array}$ & $\begin{array}{r}17,095 \\
6.5\end{array}$ \\
\hline Oil balance (in percent of GDP) $2 /$ & 2.5 & 0.0 & -2.4 & -3.0 & -1.8 & -2.1 & -2.8 & -3.9 & -5.0 & -6.1 \\
\hline
\end{tabular}

Sources: Central Bank of Syria; and staff estimates and projections.

1/ Include the NFA of the Commercial Bank of Syria.

2/ Oil trade balance less profits of foreign companies. 
Table 5. Syrian Arab Republic: Medium-Term Macroeconomic Framework, 2005-14

\begin{tabular}{|c|c|c|c|c|c|c|c|c|c|c|}
\hline & & & Est. & Prel. & & & Proj & & & \\
\hline & 2005 & 2006 & 2007 & 2008 & 2009 & 2010 & 2011 & 2012 & 2013 & 2014 \\
\hline & \multicolumn{10}{|c|}{ (Change in percent, unless otherwise indicated) } \\
\hline \multicolumn{11}{|l|}{ National income and prices } \\
\hline Real GDP & 4.5 & 5.1 & 4.3 & 5.2 & 4.0 & 5.0 & 5.5 & 5.6 & 5.6 & 5.6 \\
\hline Oil & -8.6 & -7.1 & -4.8 & 0.0 & 0.2 & 0.2 & 0.0 & -0.8 & -1.8 & -2.4 \\
\hline Non-oil & 7.5 & 6.9 & 5.8 & 6.0 & 4.5 & 5.5 & 6.0 & 6.3 & 6.5 & 6.5 \\
\hline Nominal GDP (LS billions) & 1,491 & 1,709 & 2,025 & 2,535 & 2,437 & 2,758 & 3,062 & 3,372 & 3,704 & 4,074 \\
\hline Of which: Non-oil & 1,134 & 1,305 & 1,558 & 1,896 & 2,037 & 2,261 & 2,517 & 2,806 & 3,136 & 3,505 \\
\hline Nominal GDP ( $\$$ billions) & 28.6 & 33.5 & 40.6 & 54.5 & 52.5 & 59.4 & 66.0 & 72.7 & 79.8 & 87.8 \\
\hline Crude oil production ('000 barrels/day) & 431 & 400 & 381 & 381 & 382 & 383 & 383 & 380 & 373 & 364 \\
\hline Syrian oil export price (\$ per barrel) & 48.1 & 57.6 & 65.3 & 84.2 & 52.4 & 64.3 & 69.4 & 71.7 & 73.2 & 74.9 \\
\hline CPI period average & 7.2 & 10.4 & 4.7 & 15.2 & 2.5 & 5.0 & 5.0 & 5.0 & 5.0 & 5.0 \\
\hline Government finances $1 /$ & \multicolumn{10}{|c|}{ (In percent of GDP, unless otherwise indicated) } \\
\hline Revenue & 24.0 & 25.5 & 22.7 & 19.4 & 21.9 & 21.5 & 21.6 & 21.6 & 21.6 & 21.5 \\
\hline Oil revenue & 7.1 & 7.3 & 4.9 & 5.2 & 4.6 & 5.4 & 4.1 & 4.1 & 4.0 & 3.8 \\
\hline Non-oil revenue & 16.9 & 18.2 & 17.8 & 14.2 & 17.3 & 16.1 & 17.4 & 17.5 & 17.6 & 17.7 \\
\hline Expenditure & 28.5 & 26.6 & 26.6 & 22.1 & 27.3 & 25.9 & 25.0 & 25.1 & 25.3 & 25.3 \\
\hline Current expenditure & 18.1 & 16.3 & 17.0 & 15.3 & 17.1 & 16.4 & 15.5 & 15.5 & 15.7 & 15.7 \\
\hline Development expenditure & 10.4 & 10.3 & 9.6 & 6.8 & 10.3 & 9.6 & 9.6 & 9.6 & 9.5 & 9.5 \\
\hline Overall balance & -4.5 & -1.1 & -4.0 & -2.8 & -5.5 & -4.4 & -3.4 & -3.5 & -3.7 & -3.8 \\
\hline Non-oil budget balance & -11.6 & -8.4 & -8.9 & -7.9 & -10.0 & -9.8 & -7.6 & -7.6 & -7.7 & -7.6 \\
\hline Gross public debt $2 /$ & 35.1 & 34.5 & 28.3 & 21.8 & 21.0 & 22.4 & 20.8 & 21.7 & 22.9 & 24.3 \\
\hline Domestic & 11.7 & 15.3 & 13.8 & 11.3 & 10.6 & 13.3 & 12.7 & 14.4 & 16.1 & 18.1 \\
\hline External 2/ & 23.4 & 19.2 & 14.5 & 10.5 & 10.4 & 9.1 & 8.1 & 7.4 & 6.8 & 6.3 \\
\hline \multicolumn{11}{|l|}{ Saving/investment balance } \\
\hline Consumption & 82.1 & 81.4 & 82.9 & 84.7 & 80.6 & 81.1 & 80.4 & 79.6 & 79.2 & 79.1 \\
\hline Public & 12.8 & 11.6 & 13.0 & 11.0 & 11.4 & 10.7 & 10.7 & 10.7 & 10.7 & 10.7 \\
\hline Private & 69.4 & 69.8 & 69.9 & 73.7 & 69.3 & 70.4 & 69.7 & 68.9 & 68.5 & 68.4 \\
\hline Gross capital formation & 21.7 & 23.0 & 22.4 & 20.1 & 24.0 & 23.5 & 23.6 & 24.3 & 24.9 & 25.1 \\
\hline Public & 9.3 & 9.3 & 8.7 & 6.2 & 9.3 & 8.6 & 8.6 & 8.6 & 8.6 & 8.6 \\
\hline Private & 12.3 & 13.6 & 13.8 & 13.9 & 14.7 & 14.8 & 15.0 & 15.7 & 16.3 & 16.4 \\
\hline Gross savings & 19.4 & 21.1 & 20.3 & 16.5 & 19.5 & 19.6 & 20.1 & 20.8 & 21.2 & 21.4 \\
\hline Saving/investment gap & -2.3 & -1.8 & -2.2 & -3.6 & -4.5 & -3.9 & -3.5 & -3.6 & -3.7 & -3.7 \\
\hline
\end{tabular}

Sources: Syrian authorities; and Fund staff estimates and projections.

1/ Including the Price Stabilization Fund and a broad coverage of public enterprises.

2/ The sharp decline in 2005 is due to the rescheduling of the old soviet debt that took place in early 2005. 
Table 6. Syrian Arab Republic: Financial Soundness Indicators of the Banking Sector, 2006-Sept. 2009 1/

\begin{tabular}{|c|c|c|c|c|c|c|c|c|c|c|c|c|c|c|}
\hline \multirow[b]{3}{*}{ Capital Adequacy } & \multicolumn{3}{|c|}{2006} & \multicolumn{3}{|c|}{2007} & \multicolumn{4}{|c|}{2008} & \multicolumn{4}{|c|}{ Sept. 2009} \\
\hline & Consolidated & Public & Private & Consolidated & Public & Private & Consolidated & Public & Private & Islamic & Consolidated & Public & Private & Islamic \\
\hline & & & & & & & & & & & & & & \\
\hline Regulatory capital to risk-weighted assets & $\ldots$ & $\ldots$ & $\ldots$ & $\ldots$ & $\ldots$ & 16.4 & 21.0 & 22.0 & 0.2 & 28.8 & 20.8 & 23.1 & 15.3 & 18.5 \\
\hline Regulatory tier I capital to risk-weighted assets & $\ldots$ & $\ldots$ & $\ldots$ & $\ldots$ & $\ldots$ & 16.4 & 21.0 & 22.0 & 16.6 & 28.8 & 20.8 & 23.1 & 15.3 & 18.5 \\
\hline Capital to assets & 7.0 & 7.0 & 6.9 & 6.5 & 6.5 & 6.4 & 6.5 & 6.2 & 6.6 & 16.3 & 6.5 & 6.1 & 7 & 11.3 \\
\hline \multicolumn{15}{|l|}{ Asset Composition and Quality } \\
\hline \multicolumn{15}{|l|}{ Sectoral distribution of loans to total loans } \\
\hline Agriculture & 16.7 & 18.0 & 0.1 & 15.7 & 17.4 & 0.1 & 3.7 & 4.3 & 0.3 & 0.1 & 5.9 & 7.1 & 0.2 & 0.1 \\
\hline Mining, Manufacturing, and Utilities & 8.1 & 6.8 & 24.9 & 8.0 & 4.0 & 16.3 & 7.9 & 4.8 & 24.8 & 25.6 & 7.2 & 4.4 & 18.1 & 34.4 \\
\hline Building and Construction & 14.4 & 15.4 & 2.4 & 13.9 & 15.6 & 4.3 & 14.5 & 16.6 & 2.7 & 4.5 & 16.9 & 19.9 & 3.1 & 0.4 \\
\hline Wholesale and Retail Trade & 41.3 & 41.4 & 40.1 & 41.7 & 47.7 & 44.3 & 61.0 & 64.9 & 40.4 & 36.5 & 53 & 57 & 34.7 & 35.2 \\
\hline Other Activities & 19.5 & 18.5 & 32.4 & 20.7 & 15.3 & 35.1 & 14.2 & 10.8 & 32.2 & 33.3 & 17.7 & 12.3 & 44.2 & 29.9 \\
\hline Non-performing loans to total loans & 4.7 & 5.0 & 1.0 & 5.3 & 5.9 & 1.0 & 5.1 & 5.9 & 1.0 & 0.0 & 5.1 & 5.9 & 1.4 & 2.8 \\
\hline Specific provisions to gross non performing loans & 61.0 & 61.3 & 41.7 & 23.7 & 22.0 & 92.0 & 18.1 & 17.0 & 60.4 & $\ldots$ & 17.9 & 16.6 & 45.2 & 14.8 \\
\hline Non performing loans net of provisions to Tier I capital & 6.3 & 6.8 & 1.5 & 14.4 & 16.1 & 0.3 & 25.6 & 33.2 & 1.7 & 0.0 & 25 & 31.4 & 3.6 & 10.6 \\
\hline Specific provisions to gross loans & 2.9 & 3.1 & 0.4 & 1.3 & 1.3 & 0.9 & 0.9 & 1.0 & 0.6 & 0.0 & 0.9 & 1.0 & 0.6 & 0.4 \\
\hline \multicolumn{15}{|l|}{ Profitability } \\
\hline Return on average assets (ROAA) & 2.0 & 2.3 & 0.3 & 2.4 & 2.8 & 0.5 & 1.8 & 2.1 & 0.7 & 0.1 & 1.3 & 1.6 & 0.5 & -0.1 \\
\hline Return on average equity (ROAE) & 19.6 & 21.2 & 3.9 & 23.9 & 26.1 & 7.7 & 19.1 & 22.0 & 9.7 & 0.8 & 14.7 & 17.8 & 6.4 & -0.9 \\
\hline Net interest margin to gross income & 41.8 & 40.1 & 85.9 & 77.3 & 77.2 & 78.2 & 62.7 & 60.2 & 80.6 & 52.2 & 84.1 & 88.6 & 72.2 & 56.2 \\
\hline Non-interest income to gross income & 22.7 & 22.7 & 22.7 & 22.7 & 22.8 & 21.8 & 37.3 & 39.8 & 19.4 & 47.8 & 15.9 & 11.4 & 27.8 & 43.8 \\
\hline Trading and foreign exchange income to gross income & & & & & & & -3.9 & -4.6 & -1.0 & 24.3 & 9.4 & 10.0 & 5.1 & 27.8 \\
\hline Non-interest expenses to gross income & 36.4 & 35.3 & 63.7 & 18.3 & 13.9 & 56.2 & 48.3 & 46.8 & 55.0 & 90.7 & 27.4 & 12.7 & 67.3 & 107.0 \\
\hline Non-interest expenses to average assets & 1.8 & 1.9 & 0.9 & 0.6 & 0.5 & 1.1 & 1.8 & 1.9 & 1.4 & 1.2 & 0.5 & 0.2 & 1.3 & 1.4 \\
\hline \multicolumn{15}{|l|}{ Liquidity } \\
\hline Liquid assets to total assets & 59.6 & 57.7 & 73.4 & 44.1 & 38.9 & 70.1 & 35.9 & 33.6 & 45.0 & 38.7 & 35.9 & 33.3 & 42.9 & 48.7 \\
\hline Liquid assets to short term liabilities & 102.2 & 103.7 & 95.0 & 59.6 & 54.1 & 82.6 & 56.2 & 56.0 & 56.0 & 64.4 & 54 & 52.5 & 54.8 & 83.1 \\
\hline FX- loans to total loans & 1.5 & 0.8 & 10.2 & 2.5 & 1.5 & 9.7 & 3.0 & 1.1 & 13.6 & 9.7 & 2.7 & 0.9 & 10.8 & 10.1 \\
\hline FX- deposits to total deposits & 19.3 & 11.8 & 54.0 & 20.4 & 12.0 & 49.4 & 20.4 & 10.8 & 43.3 & 64.5 & 16.4 & 6.4 & 40.1 & 26.7 \\
\hline FX- liabilities to total assets & 37.7 & 35.8 & 50.8 & 43.1 & 42.4 & 46.5 & 22.7 & 18.1 & 40.2 & 33.1 & 19.9 & 14.8 & 36.1 & 31.7 \\
\hline FX- liabilities to total liabilities & 42.1 & 40.1 & 54.9 & 47.9 & 47.4 & 50.0 & 25.0 & 20.0 & 43.6 & 39.1 & 21.8 & 16.3 & 39.4 & 35.4 \\
\hline Deposits to assets & 57.2 & 53.7 & 80.8 & 57.0 & 52.9 & 77.5 & 61.7 & 56.8 & 81.6 & 62.0 & 64.3 & 58.6 & 82.7 & 75.8 \\
\hline Loans to deposits & 61.0 & 69.2 & 23.5 & 62.0 & 70.3 & 33.6 & 72.6 & 84.9 & 40.0 & 49.5 & 68 & 81.3 & 38.9 & 39.5 \\
\hline FX- loans to FX-deposits & 4.6 & 4.8 & 4.4 & 7.6 & 8.8 & 6.6 & 10.6 & 8.4 & 12.6 & 7.4 & 11.1 & 11.6 & 10.5 & 14.9 \\
\hline \multicolumn{15}{|l|}{ Sensitivity to Market Risk } \\
\hline Net open FX position (overall) as percent of Tier I capital & 225.0 & 241.3 & 64.8 & 138.1 & 145.0 & 80.7 & 58.0 & 60.2 & 50.9 & 52.3 & 72.2 & 77.6 & 52.1 & 71.5 \\
\hline
\end{tabular}

Source: Central Bank of Syria.

1/ Financial Soundess Indicators need to be interpreted with caution due to persisting deficiencies in banks'

implementation of International Financial Reporting Standards, their audit practices, and reporting standards. 
Table 7a. Syrian Arab Republic: Public Sector Debt Sustainability Framework, 2004-2014

(In percent of GDP, unless otherwise indicated)

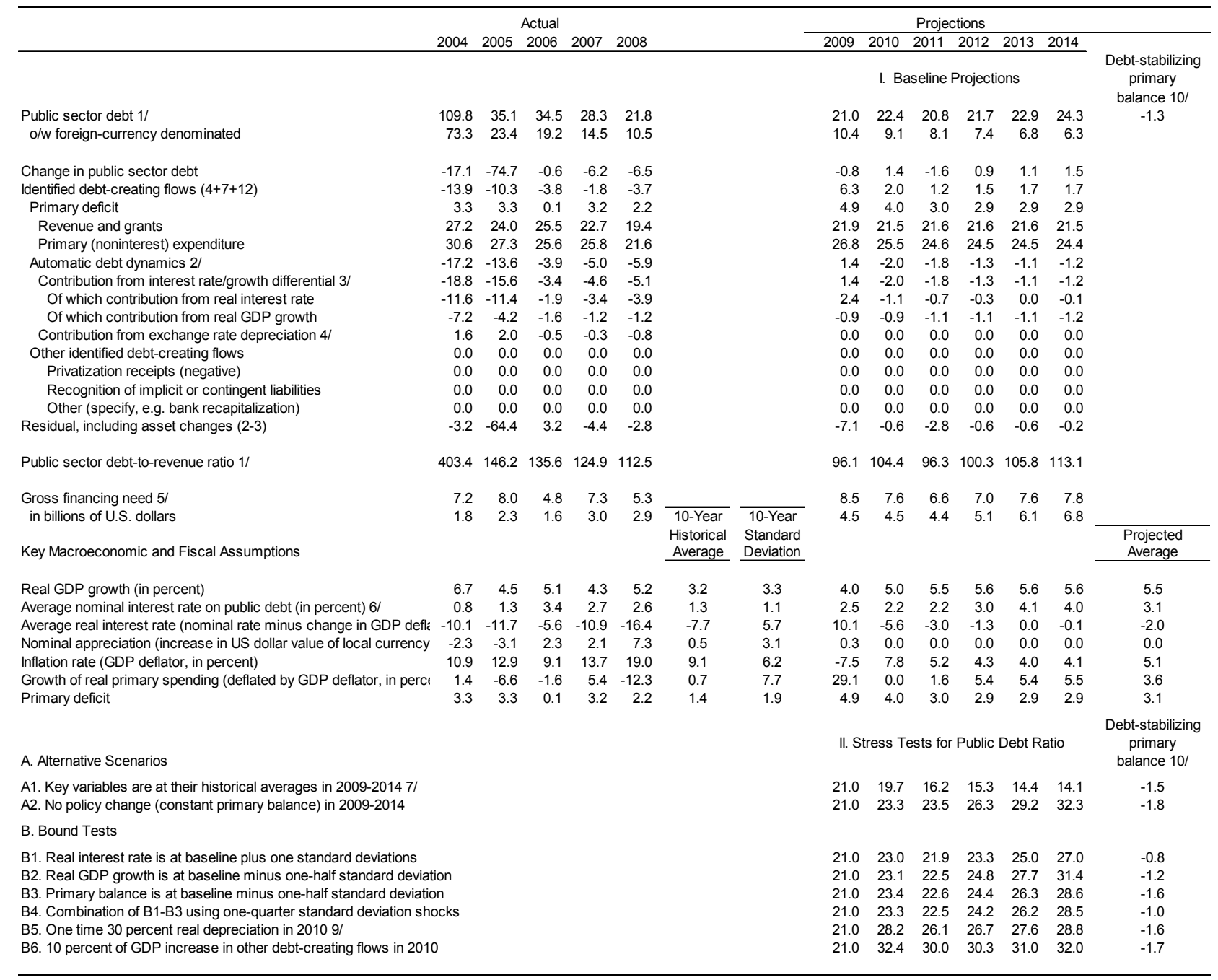

1/ Indicate coverage of public sector, e.g., general government or nonfinancial public sector. Also whether net or gross debt is used.

2/ Derived as $[(r-p(1+g)-g+a e(1+r)](1+g+p+g p))$ times previous period debt ratio, with $r=$ interest rate; $p=$ growth rate of GDP deflator; $g=$ real GDP growth rate; $a=$ share of foreign-

currency denominated debt, and $\mathrm{e}=$ nominal exchange rate depreciation (measured by increase in local currency value of U.S. dollar).

$3 /$ The real interest rate contribution is derived from the denominator in footnote $2 /$ as $r-\pi(1+g)$ and the real growth contribution as $-g$

4/ The exchange rate contribution is derived from the numerator in footnote $2 /$ as ae(1+r)

$5 /$ Defined as public sector deficit, plus amortization of medium and long-term public sector debt, plus short-term debt at end of previous period.

7/ Derived as nominal interest expendture divided by previous period debt stock.

g/ Real depreciation is definer as nominales under this scenario is discussed in the text.

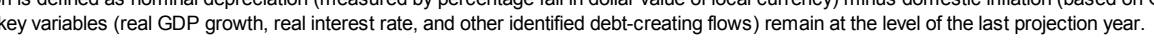


Table 7.b. Syrian Arab Republic: External Debt Sustainability Framework, 2004-2014

(In percent of GDP, unless otherwise indicated)

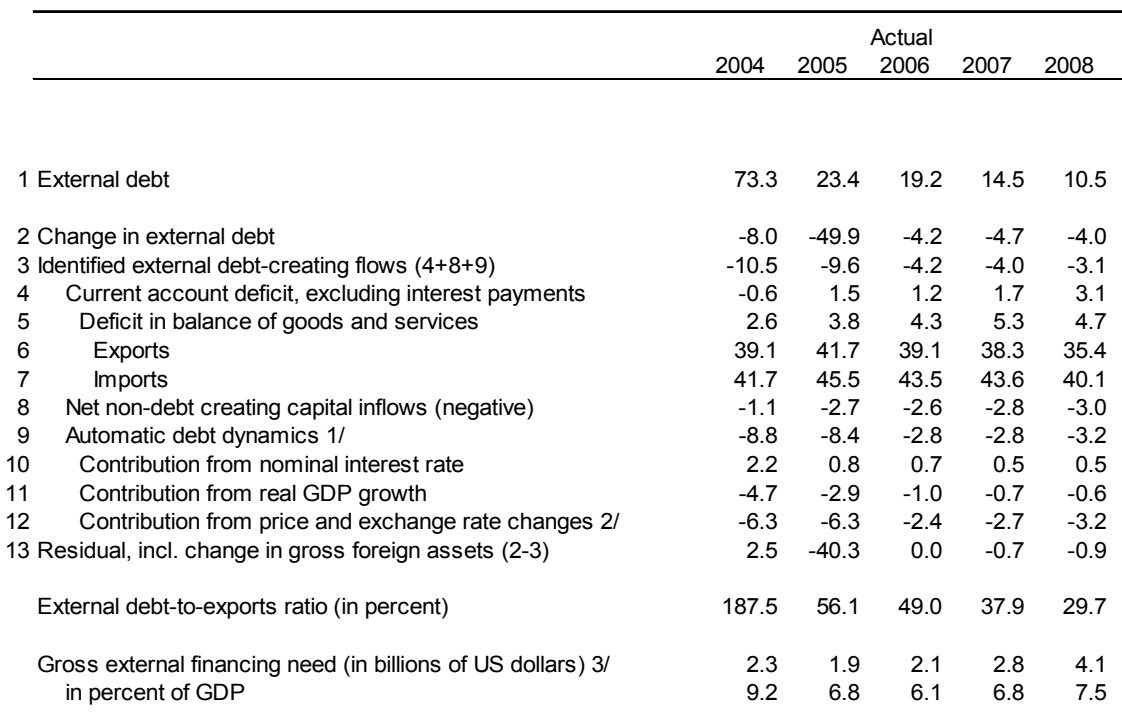
in percent of GDP

Key Macroeconomic Assumptions

Real GDP growth (in percent)

Exchange rate appreciation (US dollar value of local currency, cha GDP deflator in US dollars (change in percent)

Nominal external interest rate (in percent)

Growth of exports (US dollar terms, in percent)

Growth of imports (US dollar terms, in percent)

Current account balance, excluding interest payments

Net non-debt creating capital inflows

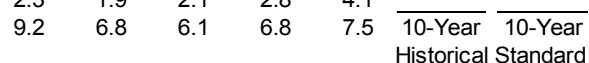

Historical Standard
Average Deviation

$\begin{array}{rrrrr}6.7 & 4.5 & 5.1 & 4.3 & 5.2 \\ -2.3 & -3.1 & 2.3 & 2.1 & 7.3 \\ 8.4 & 9.4 & 11.6 & 16.1 & 27.7 \\ 3.1 & 1.2 & 3.4 & 3.3 & 4.4 \\ 33.7 & 21.9 & 10.1 & 18.5 & 24.1 \\ 24.0 & 24.7 & 12.1 & 21.5 & 23.5 \\ 0.6 & -1.5 & -1.2 & -1.7 & -3.1 \\ 1.1 & 2.7 & 2.6 & 2.8 & 3.0\end{array}$

3.2
0.5
9.7
2.9
15.
16.
2.1
1.7

Projections

$\begin{array}{llll}2011 & 2012 & 2013 & 2014\end{array}$

Debt-stabilizing

non-interest

I. Baseline Projections

count $6 /$

$\begin{array}{lllllll}10.4 & 9.1 & 8.1 & 7.4 & 6.8 & 6.3 & -4.3\end{array}$

$\begin{array}{lllllll}-0.1 & -1.3 & -1.0 & -0.7 & -0.6 & -0.5 & 0.0\end{array}$

$\begin{array}{lllllll}2.0 & -0.4 & -0.4 & -0.9 & -1.1 & -1.0 & 0.0\end{array}$

$\begin{array}{lllllll}4.0 & 3.5 & 3.1 & 3.2 & 3.3 & 3.3 & 4.3\end{array}$

$\begin{array}{rrrrrr}4.6 & 4.5 & 4.0 & 3.9 & 4.1 & 13.1\end{array}$

$\begin{array}{llllll}36.4 & 35.6 & 34.9 & 31.1 & 31.4 & 31.8 \\ -2.9 & -3.1 & -3.1 & -3.7 & 35.5 & 44.9\end{array}$

$\begin{array}{llllllll}-2.9 & -3.1 & -3.1 & -3.7 & -4.1 & -4.0 & -4.0\end{array}$

$\begin{array}{rrrrrrr}-2.9 & -3.1 & -3.1 & -3.7 & -4.1 & -4.0 & -4.0 \\ 0.9 & -0.8 & -0.5 & -0.4 & -0.3 & -0.3 & -0.2\end{array}$

$\begin{array}{rrrrrrr}0.5 & 0.4 & 0.4 & 0.4 & 0.4 & 0.3 & 0.3\end{array}$

$\begin{array}{lllllll}-0.4 & -0.5 & -0.4 & -0.4 & -0.4 & -0.3 & -0.3\end{array}$

$\begin{array}{lllllll}0.8 & -0.8 & -0.5 & -0.3 & -0.3 & -0.3 & -0.2\end{array}$

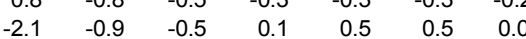

$\begin{array}{llllll}32.7 & 29.3 & 26.3 & 23.7 & 21.6 & 19.7\end{array}$

$\begin{array}{llllll}4.5 & 4.6 & 4.8 & 5.3 & 5.9 & 6.4 \\ 8.6 & 7.8 & 7.3 & 7.2 & 7.3 & 7.3\end{array}$

stabilization

Projected
Average

$\begin{array}{rrrrrrr}4.0 & 5.0 & 5.5 & 5.6 & 5.6 & 5.6 & 5.6 \\ 0.3 & 0.0 & 0.0 & 0.0 & 0.0 & 0.0 & 0.0 \\ -7.3 & 7.8 & 5.2 & 4.3 & 4.0 & 4.1 & 4.1 \\ 4.6 & 4.9 & 5.1 & 5.2 & 5.4 & 5.6 & 5.6 \\ -13.5 & 10.6 & 10.3 & 10.9 & 11.0 & 11.4 & \\ -12.6 & 10.7 & 8.9 & 10.4 & 11.4 & 39.2 & \\ -4.0 & -3.5 & -3.1 & -3.2 & -3.3 & -3.3 & \\ 2.9 & 3.1 & 3.1 & 3.7 & 4.1 & 4.0 & \end{array}$

\section{A. Alternative Scenarios}

A1. Key variables are at their historical averages in 2009-2014 4/

II. Stress Tests for External Debt Ratio

B. Bound Tests

B1. Nominal interest rate is at baseline plus one-half standard deviation

B2. Real GDP growth is at baseline minus one-half standard deviations

B3. Non-interest current account is at baseline minus one-half standard deviations

B4. Combination of B1-B3 using 1/4 standard deviation shocks

B5. One time 30 percent real depreciation in 2010

$\begin{array}{rrrrrr}10.4 & 9.1 & 8.2 & 7.5 & 6.9 & 6.5 \\ 10.4 & 9.2 & 8.2 & 7.4 & 6.7 & 6.0 \\ 10.4 & 11.9 & 13.6 & 15.4 & 17.3 & 19.2 \\ 10.4 & 10.6 & 11.0 & 11.5 & 12.2 & 12.8 \\ 10.4 & 12.2 & 8.9 & 5.9 & 3.2 & 0.7\end{array}$

1/ Derived as $[r-g-r(1+g)+e a(1+r)] /(1+g+r+g r)$ times previous period debt stock, with $r=$ nominal effective interest rate on external debt; $r=$ change in domestic GDP deflator in US dollar terms, $g=$ real GDP growth rate, $e=$ nominal appreciation (increase in dollar value of domestic currency), and $a=$ share of domestic-currency denominated debt in total external debt.

Westic currency ( $e>0$ ) and rising inflation (based on GDP deflator).

$3 /$ Defined as current account deficit, plus amortization on medium- and long-term debt, plus short-term debt at end of previous period.

4/ The key variables include real GDP growth; nominal interest rate; dollar deflator growth; and both non-interest current account and non-debt inflows in percent of GDP.

$5 /$ The implied change in other key variables under this scenario is discussed in the text.

levels of the last projection year. 


\title{
INTERNATIONAL MONETARY FUND
}

\section{SYRIAN ARAB REPUBLIC}

\section{Staff Report for the 2009Article IV Consultation-Informational Annex}

Prepared by Middle East and Central Asia Department

(In consultation with other departments)

\author{
February 12, 2010
}

Contents

Annexes

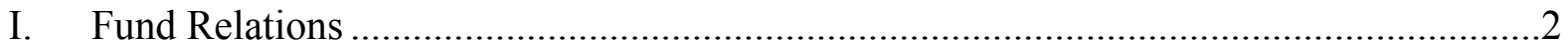

II. Relations with the World Bank Group..................................................................5

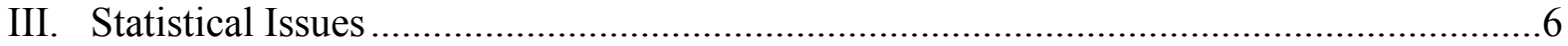


AnNex I. Syrian Arab REPUblic: Fund Relations

(As of December 31, 2009)

I. Membership Status: Joined April 10, 1947; Article XIV

II. General Resources Account:

Quota $^{1}$

Fund holdings of currency

Reserve position in Fund

III. SDR Department:

Net cumulative allocation Holdings
SDR Million

293.00

293.60

0.01

SDR Million

279.18

279.19

IV. Outstanding Purchases and Loans: None

V. Financial Arrangements: None

\section{Percent of Quota}

100.00

100.00

0.00

Percent of Allocation

100.00

100.00

VI. Projected Obligations to Fund: (SDR million; based on existing use of resources and present holdings of SDRs):

\begin{tabular}{lrrrrr}
\hline & \multicolumn{5}{c}{ Forthcoming } \\
\cline { 2 - 6 } & 2010 & 2011 & 2012 & 2013 & 2014 \\
\hline Charges/Interest & 0.02 & 0.02 & 0.02 & 0.02 & 0.02 \\
Total & 0.02 & 0.02 & 0.02 & 0.02 & 0.02 \\
\hline
\end{tabular}

\section{Exchange Rate Arrangement}

The Central Bank of Syria issues on a daily basis quotations for the buying and selling exchange rates for the Syrian pound against major currencies. The official budget exchange rate, which was applied to all public sector transactions, was pegged to the U.S. dollar until end-December 2006. Since the abolition of the official "budget" rate on January 1, 2007 and its unification with the private sector exchange rate, the central bank has been managing the value of the currency vis-à-vis the U.S. dollar within a tight trading range. The authorities switched the reference currency from the U.S. dollar to the SDR in August 2007. The de facto exchange rate arrangement is classified as a peg to a basket.

\footnotetext{
${ }^{1}$ Under the Eleventh General Review.
} 


\section{Article IV Consultations}

Syria is on an annual consultation cycle. The last Article IV consultation was held in November 2008 and was completed by the Board on January 7, 2008 (SM/08/358).

\section{Article XIV and Article VIII Restrictions}

Syria continues to maintain, under Article XIV, restrictions on payments and transfers for current international transactions, including administrative allocation of foreign exchange. Syria also maintains exchange measures that are subject to Fund approval under Article VIII: (i) prohibition against purchases by private parties of foreign exchange from the banking system for some current international transactions; (ii) a multiple currency practice resulting from divergences of more than 2 percent between the official exchange rate and officially recognized market exchange rates; (iii) a non-interest-bearing advance import deposit requirement of 75-100 percent for public sector imports; and (iv) an exchange restriction arising from the net debt under inoperative bilateral payments arrangements with the Islamic Republic of Iran, and Sri Lanka.

The Executive Board adopted decision No. 14520 (10/1) on December 30, 2009:

36. Fund takes this decision in concluding the 2009 Article XIV consultation with the Syrian Arab Republic.

37. The Syrian Arab Republic continues to maintain restrictions on the making of payments and transfers for current international transactions, including administrative allocation of foreign exchange, under the transitional arrangements under Article XIV section 2, as described in EBD/09/91, Rev. 1. In addition, the Syrian Arab Republic maintains three exchange restrictions and one multiple currency practice subject to approval under Article VIII, Sections 2(a) and 3, as described in EBD/09/91, Rev. 1. The Fund encourages the Syrian Arab Republic to eliminate the measures maintained under Article XIV as soon as its balance of payments position permits, and urges the Syrian Arab Republic to eliminate the exchange restrictions and multiple currency practice that are subject to approval under Article VIII as soon as possible. (EBD/09/91, Rev. 1, 12/23/09) (EBD/09/91, 12/22/09) 


\section{Technical Assistance}

\begin{tabular}{|c|c|c|}
\hline Department & Topic & Date \\
\hline METAC & Reform of Internal Audit & Ongoing \\
\hline METAC & Balance of Payments & Ongoing \\
\hline METAC & Banking Supervision & Ongoing \\
\hline METAC & Budget Integration & February 2009 \\
\hline $\mathrm{MCM}$ & Debt Market Development & April 2009 \\
\hline FAD & Tax administration & July 2008 \\
\hline STA & $\begin{array}{l}\text { Multi-Sector Statistics (National Accounts, Fiscal, Monetary, } \\
\text { and Balance of Payments) }\end{array}$ & December 2007 \\
\hline $\mathrm{MCM}$ & $\begin{array}{l}\text { Strategic Planning at the Central Bank of Syria and New } \\
\text { Central Bank Law }\end{array}$ & November 2006 \\
\hline FAD & Public Financial Management & February 2006 \\
\hline METAC & Revenue Administration & Ongoing \\
\hline METAC & Consumer Price Index & Ongoing \\
\hline MFD & $\begin{array}{l}\text { Long-Term Advisors on Central Bank Accounting, Reserves } \\
\text { Management, and Monetary Policy Issues }\end{array}$ & Ongoing \\
\hline MFD & $\begin{array}{l}\text { Foreign Exchange Market Development, Unification and } \\
\text { Exchange Regime }\end{array}$ & January 2006 \\
\hline LEG/MFD & AML/CFT outreach training & December 2005 \\
\hline MFD & Long-Term Advisor on Securities Market & September 2005 \\
\hline MFD & $\begin{array}{l}\text { Centralization of Official Foreign Reserves and Associated } \\
\text { Accounting, Reserves and Public Debt Management Issues }\end{array}$ & September 2005 \\
\hline \multirow[t]{2}{*}{ METAC } & National Accounts & Ongoing \\
\hline & Bank Regulation and Supervision & Ongoing \\
\hline MFD & Re-organization of the Central Bank of Syria & May 2005 \\
\hline FAD & Revenue Administration & March 2005 \\
\hline LEG/MFD & AML/CFT legal drafting & Feb/March 2005 \\
\hline STA & $\begin{array}{l}\text { Multi-Sector Statistics (National Accounts, Fiscal, Monetary, } \\
\text { and Balance of Payments) }\end{array}$ & June 2004 \\
\hline FAD & Value-Added Tax & July 2004 \\
\hline MAE & $\begin{array}{l}\text { Two Long-Term Advisors on Bank Regulation and } \\
\text { Supervision }\end{array}$ & $2002-2004$ \\
\hline
\end{tabular}




\section{AnNeX II. Syrian Arab Republic: Relations With the WorLd BANK GRouP²}

\section{(End-January 2010)}

Syria joined the World Bank in 1947. Between 1963 and 1974, IDA approved four credits for Syria totaling US\$48.6 million. Following Syria's graduation from IDA in 1974, IBRD approved 15 loans during the period 1974-86. In 1986 Syria ceased debt service payments to the Bank, which prompted a suspension of Bank disbursements. Following several rounds of negotiations with the Bank, by July 1, 2002, Syria settled all its overdue service payments to IBRD and IDA, thereby reinstating the country's eligibility for disbursement.

There is currently no World Bank Country Assistance Strategy (CAS) for Syria. A Memorandum of Understanding (MoU) covering the period 2005-07 provided the framework for the Bank's program of advisory and analytical (AAA) services. The MoU allowed the Bank to support reforms in areas of economic growth and transition, along with human development and social protection. Activities have included, among others: (i) advise on restructuring public banks and establishing a government securities market; (ii) FIAS support provided in reviewing the recently adopted Investment Law; and (iii) analytical work on energy subsidies and advise on drafting a Basic Finance Law and improving public financial management.

The Bank's current assistance to Syria comprises a program of technical assistance and advisory services in support of economic growth and transition, including policy advice on private sector development, as well as on human development, social protection and environmental sustainability. Activities cover the following areas:

- Economic Growth and Transition Support. Trade policy reform; Public Expenditure policies; Sources of non-oil growth (Country Economic Memorandum); Private sector development and business environment; Public - Private Partnerships (PPP); Governance and Public Financial Management Reform; Statistical capacity.

- Human Development and Social Protection. Labor market and employment; Enhancing policymaking and implementation capacity in social protection; Reform options for social insurance; Education sector strategy, Support to avian influenza preparedness.

- Sustainable Development. Electricity sector strategy; Agriculture and irrigation sector reform; Transport sector technical assistance.

IFC has been active in Syria since 1999 when the Board approved the corporation's first investment in the country - a $\$ 1$ million equity stake in a manufacturer of drip irrigation systems. Since that time, IFC has made two other investments, including an equity position in the first private sector bank in Syria and a loan to a chemicals company. The total held portfolio is $\$ 20.2$ million. IFC has also conducted technical assistance work, including studies of aspects of the financial sector.

\footnotetext{
${ }^{2}$ World Bank TA mission focusing on trade, fiscal issues, and the development of a SAM for Syria will overlap with the 2008 Article IV Consultation mission, facilitating Bank-Fund coordination.
} 


\section{ANNEX III. Syrian ARAB RepUblic: Statistical ISSUES}

1. Data provision has serious shortcomings that significantly hamper surveillance. The weak statistical infrastructure has been unable to cope with the acceleration of structural reforms, and the inherent difficulties in recording the flows of people, goods, and money to and from Iraq have added to this challenge. The staff's assessment of economic developments and policies is constrained by these circumstances. In the context of Article IV missions, the authorities have expressed an intention to improve the statistical system. With the assistance of the 2007 multisector statistics mission, Syria began participating in the General Data Dissemination System (GDDS) in December 2007, and the plans for improving the statistical system are posted on the Fund's Dissemination Standards Bulletin Board.

\section{A. Real Sector Statistics}

2. Annual national accounts by expenditure data are reported for publication in the International Financial Statistics (IFS) with about 2-years lag. In addition, significant weaknesses remain in the source data and statistical techniques for national accounts statistics.

3. A STA-resident statistics advisor has been in place since July 2008 to help implement the recommendations of the December 2007 STA multisector mission in the area of national accounts. During the past two years, METAC has also provided technical assistance for improving data sources and methods for the compilation of national accounts statistics in accordance with the System of National Accounts, 1993 (1993 SNA). Guidance has also being provided for using existing data for improving gross domestic product (GDP) estimates at current and constant prices and for the appropriate treatment in the national accounts of implicit subsidies to some public enterprises. The Central Bureau of Statistics (CBStat) made a steady progress for implementing recommendations made by the technical assistance missions. Economic surveys covering private sector enterprises had been conducted for years 2004-2006. The central purpose of these surveys was to serve as main data source for improving national accounts statistics in accordance with the 1993 SNA; however, the results are yet to be fully processed and validated.

\section{B. Government Finance Statistics}

4. Government finance statistics (GFS) suffer from major deficiencies with respect to definitions, coverage, classification, methodology, accuracy, reliability, and timeliness that generate severe inconsistencies with monetary and balance of payments statistics. Fiscal statistics are not provided for publication in the IFS. The multisector mission of June 2004 found that compilation is adversely affected by cumbersome institutional arrangements, inadequate resources, and unresolved methodological problems. The methodology used for compilation does not follow either GFSM 2001 or GFSM 1986. While budget data are available with very long lags (two years for final budget accounts), financing data are not available. There is no dissemination of GFS data, and even access to key data sources by GFS compilers within the Ministry of Finance (MOF), such as the breakdown of debt service into interest and

Washington, D.C. 20431 • Telephone 202-623-7100 • Fax 202-623-6772 • www.imf.org 
amortization, is problematic. This contributes to discrepancies in external financing as reported in the budget and the balance of payments statistics.

5. The largest, most persistent and volatile discrepancies, are between the financing requirements of the budget, as reported by the MOF, and government financing as reported by the Central Bank of Syria (CBS). The lack of a common and regularly updated coverage of the government sector between the MOF and the CBS, misclassification of public enterprises investment expenditure, as well as timing and valuation issues, are mainly responsible for those discrepancies.

6. Other discrepancies between fiscal and monetary accounts relate to the unorthodox treatment by the CBS of some transactions with government, such as the parallel rise of government deposits and claims on government in the CBS balance sheet, which is likely due to government withdrawals being counted as credit and never netted out against deposits, and profits transferred to government treated as permanent claim on the government.

7. To address the methodological issues, the June 2004 multisector mission developed a preliminary bridge table that maps the budgetary source data codes to the GFSM 2001 classification codes, and conducted a seminar to clarify various aspects of the GFSM 2001 methodology to the MOF officials. To help the Directorate of Planning and Statistics (DPS) implement a proper sectorization scheme, the mission provided an updated institutional table showing the current coverage of government and public enterprises - the investment expenditure of public enterprises is included in government's capital expenditure-for circulation to all relevant agencies. Moreover, the mission formulated a detailed work plan centered around the provision of adequate resources and training for the DPS to fulfill its tasks. The work plan calls for the DPS to access core source data necessary for compilation-initially on a cash basis-of annual GFS data according to the GFSM 2001, and for the resumption of data reporting to STA for publication in GFSY and IFS, together with improved reporting, in terms of coverage and classification, to the IMF's Middle East and Central Asia Department (MCD). The mission also recommended improvement in the timeliness of annual data, including data on financing, and a start on the compilation of sub-annual data.

\section{Monetary and Financial Statistics}

8. Monetary statistics suffer from major deficiencies which hamper the staff's ability to conduct meaningful analysis of monetary developments. Monthly monetary statistics are reported for publication in the IFS with about 10-month lags, falling short of recommended dissemination practices under the GDDS of 3-month lags. Progress has been made in addressing some issues identified by the multisector statistics mission in June 2004, namely including in the monetary survey the private banks, the Savings Bank, and banks/bank branches operating in the Free Zones. Although the format of monetary statistics is largely consistent with the structure of the MFSM-recommended sectoral surveys, there are deficiencies in the source data arising from, inter alia, (i) the use of different exchange rates at the CBS and at the other banks for valuing 
their foreign-currency positions; (ii) financial positions are not valued at market prices or market-price equivalents; (iii) a number of accounting procedures for the maintenance of public sector accounts cause distortions in the measurement of gross positions; and (iv) there are disparities between the institutional coverage of public sector in monetary statistics and the government finance statistics.

9. A technical assistance mission during November-December 2008 worked with the authorities on developing data reporting based on the Standardized Report Forms (SRFs), which reflect the MFSM-recommended compilation principles. The mission's work was underpinned by detailed data recently provided by the authorities.

\section{External Sector Statistics}

10. Balance of payments statistics are compiled by the CBS on a provisional basis. Trade data are compiled monthly by the Customs Department and reported quarterly by the CBStat in local currency units with a six-month lag. The BOP is presented in BPM5 format, but its compilation method is not entirely consistent with the BPM5 methodology.

11. In February 2006, a STA assessment mission assessed the status of the work program as a basis for developing a METAC technical assistance program on external sector statistics. In December 2007, STA conducted a multisector statistics mission in collaboration with METAC and follow-up METAC missions took place in January and July 2008.

12. In September 2008, a STA inspection visit followed up on the recommendations of the 2007 multisector mission and METAC's work program and discussed the reporting and publication of data on international liquidity for IFS, which has been an outstanding issue for over three years.

13. Regarding the balance of payments, the mission found that the CBS had made progress in improving source statistics through surveys and International Transactions Reporting System (ITRS), by adopting appropriate classifications, and improving consistency with other data sets. The CBS's new organizational structure is designed to include a balance of payments division of five staff (currently two staff are assigned to BOP work but plans are in place to fully staff the division).

14. The October 2008 STA balance of payments statistics mission worked to provide advice on international reserves, trade data, and the treatment of Iraqi immigrants was provided, to the extent possible. Data for 2007 were adjusted where needed and the mission assisted the CBS staff to compile January-July 2008 balance of payments in BPM5 format.

15. Despite recent progress, further efforts are needed to improve the accuracy of the BOP data and the International Investment Position (IIP) to meet data needs for surveillance purposes, in particular; (i) continue data collection initiatives (ITRS and surveys) that have been developed with a view to strengthening source data, and ensuring coverage of free zones, 
(ii) improve the undercoverage of imports, (iii) examine the scope of transfers, including the treatment of inflows related to Iraqi immigrants, (iv) review the coverage of reserves, and (iv) improve the coverage of financial account data of the private sector (bank and nonbank).

16. The authorities have made some progress in the compilation of international merchandise trade statistics. The Customs Department has adopted Automated System for Customs Data (ASYCUDA) as its operating system and is presently implementing it and a Statistical Committee on Foreign Trade Statistics has been formed to assist with trade methodology. However, significant weaknesses remain in the source data and statistical techniques for foreign trade statistics. 


\section{SYRIAN ARAB REPUbLIC: TABLE OF COMMON INDICATORS REQUIRED FOR SURVEILLANCE}

As of December 31, 2009

\begin{tabular}{|c|c|c|c|c|c|}
\hline & $\begin{array}{l}\text { Date of latest } \\
\text { observation }\end{array}$ & $\begin{array}{l}\text { Date } \\
\text { received }\end{array}$ & $\begin{array}{l}\text { Frequency of } \\
\text { Data }^{7}\end{array}$ & $\begin{array}{l}\text { Frequency of } \\
\text { Reporting }^{7}\end{array}$ & $\begin{array}{l}\text { Frequency } \\
\text { of } \\
\text { publication }\end{array}$ \\
\hline Exchange Rates & Dec. 30, 2009 & $\begin{array}{l}\text { Dec. 31, } \\
2009\end{array}$ & $\mathrm{D}$ & $\mathrm{D}$ & $\mathrm{D}$ \\
\hline $\begin{array}{l}\text { International Reserve Assets and } \\
\text { Reserve Liabilities of the Monetary } \\
\text { Authorities }^{1}\end{array}$ & Sep. 2009 & Dec. 2009 & M & Q & M \\
\hline Reserve/Base Money & Sep. 2009 & Dec. 2009 & M & Q & M \\
\hline Broad Money & Sep. 2009 & Dec. 2009 & M & Q & M \\
\hline Central Bank Balance Sheet & Sep. 2009 & Dec. 2009 & M & Q & M \\
\hline $\begin{array}{l}\text { Consolidated Balance Sheet of the } \\
\text { Banking System }\end{array}$ & Sep. 2009 & Dec. 2009 & M & Q & M \\
\hline Interest Rates ${ }^{2}$ & Sep. 2009 & Dec. 2009 & M & Q & M \\
\hline Consumer Price Index & Oct. 2009 & Nov. 2009 & M & M & M \\
\hline $\begin{array}{l}\text { Revenue, Expenditure, Balance and } \\
\text { Composition of Financing }{ }^{3}-\text { General } \\
\text { Government }^{4}\end{array}$ & 2008 & Dec. 2009 & A & A & A \\
\hline $\begin{array}{l}\text { Revenue, Expenditure, Balance and } \\
\text { Composition of Financing }{ }^{3}-\text { Central } \\
\text { Government }\end{array}$ & 2008 & Dec. 2009 & A & $A$ & A \\
\hline $\begin{array}{l}\text { Stocks of Central Government and } \\
\text { Central Government-Guaranteed Debt }\end{array}$ & 2008 & Dec. 2009 & A & A & $A$ \\
\hline External Current Account Balance & 2008 & Dec. 2009 & $A$ & A & $A$ \\
\hline $\begin{array}{l}\text { Exports and Imports of Goods and } \\
\text { Services }\end{array}$ & Jun. 2009 & Dec. 2009 & Q & Q & Q \\
\hline GDP/GNP & 2008 & Dec. 2009 & $A$ & A & $A$ \\
\hline Gross External Debt & 2008 & Dec. 2009 & A & A & A \\
\hline International Investment Position ${ }^{6}$ & NA & NA & NA & NA & NA \\
\hline
\end{tabular}

1/ Includes reserve assets pledged or otherwise encumbered as well as net derivative positions.

2/ Both market-based and officially-determined, including discount rates, money market rates, rates on treasury

bills, notes and bonds.

3/ Foreign, domestic bank, and domestic nonbank financing.

4/ The general government consists of the central government (budgetary funds, extra budgetary funds, and social security funds) and state and local governments.

5/ Including currency and maturity composition.

6/ Daily (D), Weekly (W), Monthly (M), Bi-Monthly (B); Quarterly (Q), Annually (A), Irregular (I); Not Available (NA). 


\section{INTERNATIONAL MONETARY FUND \\ EXTERNAL \\ Public Information Notice

Public Information Notice (PIN) No. 10/42

FOR IMMEDIATE RELEASE

March 25, 2010
International Monetary Fund

$70019^{\text {th }}$ Street, NW

Washington, D. C. 20431 USA

\section{IMF Executive Board Concludes 2009 Article IV Consultation with the Syrian Arab Republic}

On February 26, 2010, the Executive Board of the International Monetary Fund (IMF) concluded the Article IV consultation with the Syrian Arab Republic on a lapse of time basis. $^{1}$

\section{Background}

The impact of the global financial crisis on Syria has been relatively moderate and mostly through linkages to trading partners in the GCC and Europe. GDP growth is estimated to have decelerated in 2009 by 1 percentage point to 4 percent. Lower growth in manufacturing, construction, and services was partially offset by a moderate recovery in agriculture and a small increase in oil production. Unemployment is estimated to have increased to almost 11 percent. Inflation declined sharply to about 2.5 percent, reflecting trends in global prices. Fiscal policy aimed at mitigating the impact of the global crisis. The Fiscal deficit increased by about 2.5 percentage points to 5.5 percent in 2009 . Total expenditure grew by about 5 percent of GDP, reflecting increases in public investments, as well as the wage bill and transfers to compensate for raising fuel prices and removal of petroleum subsidies. Non-oil revenue increased, partly due to strong tax collection, which resulted from improved administration and incentives to settle arrears.

\footnotetext{
${ }^{1}$ Under Article IV of the IMF's Articles of Agreement, the IMF holds bilateral discussions with members, usually every year. A staff team visits the country, collects economic and financial information, and discusses with officials the country's economic developments and policies. On return to headquarters, the staff prepares a report, which forms the basis for discussion by the Executive Board. At the conclusion of the discussion, the Managing Director, as Chairman of the Board, summarizes the views of Executive Directors, and this summary is transmitted to the country's authorities.
} 
The external current account deficit widened to about 4.5 percent, as the decline in exports exceeded that of imports. However, tourism receipts were buoyant, and both FDI and remittances dropped only slightly. Gross reserves remained comfortable, at about US $\$ 17$ billion.

With the Syrian pound pegged to a basket (within a band), broad money is estimated to have grown by about 10 percent in 2009. Credit to public enterprises decelerated sharply due to the reduction in energy subsidies, which were financed by borrowing. Nonetheless, growth of credit to the private sector remained at about 25 percent, driven by the expansion of private banks.

The outlook for 2010 and beyond point to an overall strengthening in economic performance. The ongoing recovery in Syria's trading partners is expected to contribute to a gradual increase in exports, remittances, and FDI. Agriculture is likely to continue to recover from the severe drought of the past two years. The fiscal and current account are expected to stabilize as a result of the fiscal reforms, including the introduction of value added tax (VAT) in 2011, a further deepening of subsidies reform, and expenditure restraint. A delay in global recovery or faltering reform implementation could worsen the outlook and impede Syria's economic growth.

While some progress has been made in advancing structural reforms, there were a few negative developments. Steps were taken to simplify investment procedures, modernize accounting standards, and streamline the tax system. Effective June 2009, the authorities raised the minimum thresholds for exemption from wage taxes. As an offsetting measure, the top income tax rate for individuals was increased to 22 percent (from 20 percent). The authorities also introduced reference prices and customs duties that vary by country of origin to protect against unfair trade practices.

\section{Executive Board Assessment}

Executive Directors concurred that the impact of the global financial crisis on Syria has been relatively moderate. Preliminary data for 2009 indicate that non-oil growth decelerated as lower growth in most sectors was only partially offset by a moderate recovery in agriculture. Inflation declined sharply, reflecting trends in the global prices of basic commodities. Despite the important progress made in subsidies reforms, the fiscal deficit widened as the consolidation of public finances in the past few years provided room for the authorities to implement counter-cyclical measures to mitigate the effects of the global economic crisis. The current account deficit increased slightly, as the decline in exports exceeded that of imports. Tourism receipts, however, remained buoyant, and both FDI and remittances dropped only slightly despite the global economic crisis.

Directors considered the widening in the fiscal deficit in 2009 to be appropriate to mitigate the impact of the global recession. They noted that this widening in the fiscal deficit in 2009 partly reflects enhanced fiscal transparency as substantial extra-budgetary spending related to petroleum subsidies was brought on budget. However, Directors 
underscored the need for a gradual resumption of fiscal consolidation going forward in order to preserve fiscal sustainability. In this regard, they encouraged the authorities to revisit the large increase in public investment budgeted for 2010, especially after its large increase in 2009 . They noted that this would be more in line with absorptive capacity and would help reduce the overall fiscal deficit to about 4.5 percent of GDP. Directors also urged the authorities to ensure that increases in public wages are linked to performance and to civil service reform.

Directors commended the authorities for the recent reforms of petroleum subsidies that have led to considerable efficiency gains and a reduction in waste and leakages as reflected in the decline in domestic consumption. They noted that the replacement in December 2009 of the diesel coupons with cash transfers is likely to enhance the targeting of assistance and consolidate efficiency and fiscal gains. Directors encouraged the authorities to prevent a re-emergence of the large inefficient price subsidies of the past.

Directors welcomed the substantial progress in the preparation for the VAT, but underscored the need for further efforts. They supported the emphasis on making progress in reorganizing tax administration, including by shifting more responsibilities to the General Commission for Taxes and Fees (GCTF). Directors welcomed the streamlining of the tax system, and advised against a further increase in the personal income tax rates. They encouraged the authorities to streamline excise taxes in line with the recommendations of past technical assistance missions.

Directors welcomed the efforts to improve public financial management are welcome and should continue. They recommended that the budget classification be further enhanced to reflect standardized economic classifications. In addition, Directors underscored the importance of supporting the plan to cast the budget formulation and execution in a medium-term framework by further empowering the newly established Fiscal Forecasting and Planning Units at the Ministry of Finance (MoF) and facilitating a more timely flow of data and information between these units and the different departments at the MoF. Directors encouraged the authorities to expand the use of the program- and performancebased budgeting approach. They also emphasized the importance of bringing on budget the remaining quasi-fiscal operations.

Directors underscored the need for a shift in the financing of the budget deficit from bank borrowing to issuing treasury bills. They recommended that the interest rate on these bills be market-determined. At the same time, Directors underscored the importance of ensuring that public investment projects yield high economic and social return in order to justify the cost of their financing.

Directors welcomed the progress made in implementing the reform agenda to modernize the Central Bank of Syria (CBS) and the monetary policy framework. They noted that enhancing the CBS operational independence will be important to strengthen its ability to 
formulate and implement monetary policy. Directors also encouraged the authorities to utilize treasury bills as an instrument of monetary policy to withdraw excess liquidity. They recommended that, otherwise, the CBS would have to issue its own certificates of deposit. Directors concurred that considerations be given to securitizing the stock of government debt to the CBS.

Directors encouraged the authorities to phase-out some of the decisions that were taken in response to the global crisis. They recommended that the legitimate intended objectives of differentiated reserve requirements or increased credit exposure limits for development projects be achieved through other means that are more effective and entail lower risks for banks and lesser burden for the supervision department.

Directors welcomed the good start at implementing the recommendations of the 2008 FSAP report, including by strengthening the regulatory and supervisory framework and improving collection of data on public banks. They encouraged the authorities to continue to strengthen supervision in order to maintain the health of the financial sector, especially in view of the rapid growth of private banks' credit. Directors also encouraged the authorities to adopt the amended central bank law as soon as possible.

Directors concurred that the priority in the period ahead be given to public banks' reform. They welcomed the closer collaboration between the MoF and the CBS regarding supervision of these banks. Directors noted that strengthening the CBS's supervisory and regulatory independence with respect to these banks would ensure their compliance with prudential regulations and help address deficiencies identified in the supervisory process.

Directors agreed that the Syrian pound's de jure peg to a band around the SDR can provide a strong monetary anchor, while allowing some flexibility in the pound's rate vis-àvis major currencies. They noted that in practice, the pound appears to be de facto pegged to a basket in which the dollar has a larger weight than its weight in the SDR basket. Directors concurred that adjusting the de facto basket in line with the de jure regime would be more consistent with Syria's direction of trade. They noted that the dollar has the largest share in the SDR basket, which is also consistent with the key role it has in foreign exchange markets and international trade pricing and payments. Directors considered that a gradual move toward greater flexibility over the medium-term as the monetary policy framework develops would further increase monetary policy independence and maintain external stability. Directors agreed that preliminary econometric estimates suggest that the pound may be moderately overvalued in real effective terms, although they are still subject to uncertainties given the serious data shortcomings. Directors, however, did not recommend a change in the current nominal exchange rate level in the present context.

Directors welcomed the progress made in transition to a market economy, but noted that the remaining structural reform agenda is substantial. They supported the emphasis on further reducing the number of goods subject to administrative pricing, and modernizing of 
the legal and regulatory framework in order to encourage private investment and enhance competitiveness. Directors recommended that the authorities reverse the recent introduction of customs duties that vary by country of origin, and address suspected unfair trade practices by other measures such as enhancing customs' capacity to examine invoices through computerization and cross border cooperation.

Directors welcomed the authorities' intention to accept the obligations of Article VIII of the IMF's Articles of Agreement. They recommended that the authorities remove any remaining restrictions in preparation for the acceptance of the obligations of Article VIII. Directors noted the staff readiness to conduct a comprehensive review of the exchange system upon the authorities' request.

Directors urged the authorities to improve data quality and provision to facilitate better analysis of developments and guide policy formulation.

Public Information Notices (PINs) form part of the IMF's efforts to promote transparency of the IMF's views and analysis of economic developments and policies. With the consent of the country (or countries) concerned, PINs are issued after Executive Board discussions of Article IV consultations with member countries, of its surveillance of developments at the regional level, of post-program monitoring, and of ex post assessments of member countries with longer-term program engagements. PINs are also issued after Executive Board discussions of general policy matters, unless otherwise decided by the Executive Board in a particular case. 
Syrian Arab Republic: Selected Economic Indicators, 2005-09

\begin{tabular}{|c|c|c|c|c|c|}
\hline & & & Est. & Prel. & Proj. \\
\hline & 2005 & 2006 & 2007 & 2008 & 2009 \\
\hline & \multicolumn{5}{|c|}{ (Change in percent, unless otherwise indicated) } \\
\hline \multicolumn{6}{|l|}{ National income and prices } \\
\hline Real GDP & 4.5 & 5.1 & 4.3 & 5.2 & 4.0 \\
\hline Oil & -8.6 & -7.1 & -4.8 & 0.0 & 0.2 \\
\hline Non-oil & 7.5 & 6.9 & 5.8 & 6.0 & 4.5 \\
\hline Nominal GDP (LS billions) & 1,491 & 1,709 & 2,025 & 2,535 & 2,437 \\
\hline Of which: Non-oil & 1,134 & 1,305 & 1,558 & 1,896 & 2,037 \\
\hline Nominal GDP (\$ billions) & 28.6 & 33.5 & 40.6 & 54.5 & 52.5 \\
\hline Crude oil production ('000 barrels/day) & 431 & 400 & 381 & 381 & 382 \\
\hline GDP deflator & 12.9 & 9.1 & 13.7 & 19.0 & -7.5 \\
\hline Syrian oil export price (\$ per barrel) & 48.1 & 57.6 & 65.3 & 84.2 & 52.4 \\
\hline $\mathrm{CPI}$ period average & 7.2 & 10.4 & 4.7 & 15.2 & 2.5 \\
\hline \multirow[t]{2}{*}{ Total population (millions) } & 19.3 & 20.4 & 20.8 & 21.3 & 21.8 \\
\hline & \multicolumn{5}{|c|}{ (In percent of GDP, unless otherwise indicated) } \\
\hline \multicolumn{6}{|l|}{ Government finances } \\
\hline Revenue & 24.0 & 25.5 & 22.7 & 19.4 & 21.9 \\
\hline Oil revenue & 7.1 & 7.3 & 4.9 & 5.2 & 4.6 \\
\hline Non-oil revenue & 16.9 & 18.2 & 17.8 & 14.2 & 17.3 \\
\hline Expenditure & 28.5 & 26.6 & 26.6 & 22.1 & 27.3 \\
\hline Current expenditure & 18.1 & 16.3 & 17.0 & 15.3 & 16.5 \\
\hline Development expenditure & 10.4 & 10.3 & 9.6 & 6.8 & 10.3 \\
\hline \multirow[t]{2}{*}{ Overall balance } & -4.5 & -1.1 & -4.0 & -2.8 & -5.5 \\
\hline & \multicolumn{5}{|c|}{ (Changes in percent of initial stock of money) } \\
\hline Broad money & 11.8 & 9.2 & 12.4 & 12.5 & 10.2 \\
\hline Net foreign assets & 0.1 & -2.1 & -3.4 & -7.9 & 2.6 \\
\hline Net domestic assets & 11.8 & 10.5 & 14.2 & 20.4 & 7.5 \\
\hline Credit to government & 5.3 & 1.3 & -2.9 & -4.1 & 3.0 \\
\hline Credit to public enterprises & 1.6 & 3.1 & 6.9 & 10.3 & 4.3 \\
\hline Credit to private sector & 7.0 & 2.7 & 3.8 & 5.7 & 5.9 \\
\hline \multirow[t]{2}{*}{ Credit to private sector (change in percent) } & 50.6 & 14.5 & 19.7 & 27.7 & 25.0 \\
\hline & \multicolumn{5}{|c|}{ (In billions of U.S. dollars, unless otherwise indicated) } \\
\hline \multicolumn{6}{|l|}{ Balance of payments } \\
\hline Current account balance & -0.7 & -0.6 & -0.9 & -1.9 & -2.4 \\
\hline (in percent of GDP) & -2.3 & -1.8 & -2.2 & -3.6 & -4.5 \\
\hline Overall oil balance $1 /$ & 0.7 & 0.0 & -1.0 & -1.7 & -1.0 \\
\hline (in percent of GDP) & 2.5 & 0.0 & -2.4 & -3.0 & -1.8 \\
\hline Non-oil exports of goods and services & 7.6 & 9.1 & 11.2 & 13.7 & 13.2 \\
\hline (change in percent) & 19.8 & 18.8 & 23.5 & 23.0 & -4.1 \\
\hline Non-oil imports of goods and services & -10.5 & -11.7 & -13.4 & -16.2 & -15.8 \\
\hline (change in percent) & 13.6 & 11.0 & 15.1 & 20.5 & -2.2 \\
\hline Overall balance & -0.5 & -1.2 & 0.6 & 0.1 & 0.0 \\
\hline Official net foreign assets & 17.4 & 16.5 & 17.0 & 17.1 & 17.1 \\
\hline (in months of imports of GNFS) & 16.0 & 13.6 & 11.5 & 9.4 & 10.7 \\
\hline Nominal exchange rate LS/\$ 2/ & 52.2 & 51.0 & 49.9 & 46.5 & 46.7 \\
\hline Real effective exchange rate (in percent, + appreciation) 2/ & -1.6 & 8.5 & -2.9 & 13.9 & -7.0 \\
\hline
\end{tabular}

Sources: Syrian authorities; and Fund staff estimates and projections.

1/ Oil trade balance less profit of foreign oil companies.

2/ Trade-weighted average of official and parallel market rates before 2007 . The REER for 2009 is for January-November. 